\title{
Vertical and horizontal controls of a haptophyte thin layer in the Bay of Biscay, France
}

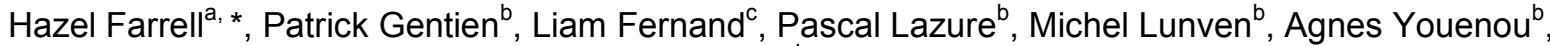 \\ Beatriz Reguera ${ }^{\mathrm{d}}$, Robin Raine ${ }^{\mathrm{a}}$
}

\footnotetext{
a The Ryan Institute for Environmental, Marine and Energy Research, National University of Ireland, Galway, University Road, Galway, Ireland

${ }^{\mathrm{b}}$ Institut Français de Recherche pour l'Exploitation de la Mer (IFREMER), Centre de Brest, Pointe du Diable, BP 7029280 Plouzane, France

${ }^{c}$ Centre for Environment Fisheries and Aquaculture Science (CEFAS), Pakefield Road, Lowestoft NR33 OHT, United Kingdom

d Instituto Espanõl de Oceanografía (IEO), Centro Oceanográfico de Vigo, Subida a Radiofaro 50-52, Cabo Estay, Canido, 36390 Vigo, Spain

*: Corresponding author : Hazel Farrell, hazel.farrell@uts.edu.au
}

\begin{abstract}
:
Investigations into the phytoplankton of the Bay of Biscay in July 2006 revealed an extensive bloom of an unidentified haptophyte species. High-resolution sampling techniques identified the region in the vicinity of the mouth of the Loire estuary as an area of high $\left(10^{6}-10^{7}\right.$ cells $\left.\left.\right|^{-1}\right)$ cell densities of the haptophyte in a thin sub-surface layer. This organism dominated the phytoplankton population regionally. Measurements of the vertical distribution of horizontal shear showed that the population, located at ca. $20 \mathrm{~m}$ depth, was confined to a layer lying between two density discontinuities with high shear. Physical measurements indicated that the population was being advected southeastwards, along the coast. Seaward spreading of the population was also noted during the survey. Horizontal diffusion could be derived from the changes in the offshore gradient in the population's distribution with time, with estimates of $K x$, the horizontal diffusion coefficient, of the order of $100 \mathrm{~m}^{2} \mathrm{~s}^{-1}$. The magnitude of horizontal dispersion is compared with that of horizontal advective flux, vertical dispersion and growth.
\end{abstract}




\section{Introduction}

Our understanding of vertical distribution of phytoplankton has historically derived from bulk measurements of parameters such as chlorophyll $a$. Typically, phytoplankton were understood to be at their maximum within the euphotic zone, with minimal values at depth (Steele and Yentsch, 1960). Relatively recently, our perception of vertical phytoplankton distributions has advanced due to improvements in the resolution of vertical profiling systems. Population maxima, with a vertical scale ranging from centimetres to metres (Hanson and Donaghay, 1998; Dekshenieks et al., 2001), have been associated with micro-gradients in temperature, salinity and density (Donaghay et al., 1992; Osborn, 1998; Cowles, 2004; Gentien et al., 2005). Such dense subsurface concentrations of phytoplankton, contained within bands of narrow vertical extent, are collectively referred to as "thin layers".

Characteristically, the densities of phytoplankton cells within thin layers are one to several orders of magnitude higher than in the mixed layers above and below the layer (McManus et al., 2003). Horizontally, they may extend for several kilometres (Cowles, 2004), while also persisting over periods from hours to days (Bjørnsen and Nielsen, 1991; Rines et al., 2002; Kononen et al., 2003; McManus et al., 2003). The majority of thin layers have been recorded in coastal systems such as bays (Tyler and Seliger, 1978), rias (Velo-Suárez et al., 2008), fjords (Dekshenieks et al., 2001; McManus et al., 2003) and the near coastal continental shelf (Cowles, 2004; Farrell et al., 2012). Harmful species have been observed within these layers (GEOHAB, 2008), which raises serious concerns regarding their potential for bloom initiation and subsequent threat to coastal resources (Donaghay and Osborn, 1997; McManus et al., 2008). In order to model and forecast these events, it is necessary to parameterise the physical and biological processes associated with the species-specific formation, maintenance and dissipation of thin layers. 
The spatial and temporal scales of interest to the formation of thin layers begin at the mesoscale level. Water column stability associated with seasonal stratification is a known precursor to the formation of thin layers (Gentien et al., 2005; GEOHAB, 2008; Raine, 2013). Fine scale mechanisms that can promote the formation of phytoplankton thin layers have been outlined by Franks (1995) and Durham and Stocker (2012). Some of these are biotic, such as convergent swimming, in situ growth, differential grazing, or physiological adaptations like changes in cell buoyancy. However, the passive nature of plankton means that small scale physical processes can be primary influences underlying their vertical distribution. The resolution of the vertical velocity gradient has been recognised as an important parameter in thin layer research (Cowles, 2004, Ryan et al., 2008). Sharp vertical gradients in the flow field (shear) can convert diffuse heterogeneity in the phytoplankton distribution into sharp gradients of increasing magnitude over narrow vertical distances (Thorpe, 2007). The tilting and stretching (straining) of a patch of phytoplankton into a thin layer was explored numerically by Franks (1995), Stacey et al., (2007) and Birch et al. (2008) with the conclusions that the strength of the shear, original patch size and time are determining factors. Their theoretical, numerical models demonstrate the spatial scales over which relevant measurements must be made in order to further our understanding of the physical dynamics involving shear and thin layers.

The Bay of Biscay is highly dynamic and subject to a range of physical processes (Koutsikopoulos and Le Cann, 1996). On the shelf, currents may be explained by a combination of wind-driven, tidally induced and density driven flows (Pingree and Le Cann, 1989). Circulation in the surface (<80 m) layer has recently been described by Charria et al. (2011), who show seasonal patterns based on 281 drifter trajectories made between 1992 and 2009. In the northeastern area of the bay, on the Armorican Shelf, freshwater discharges from the Loire induce important density gradients and drive a poleward circulation, modulated by wind forcing, and northwestards flows are 
observed here in autumn and winter (Chiarra et al., 2011). Seasonal variations occur in this flow, which is slack in spring and southeastwards in summer (July-September) under typically northwest winds and reduced influence of the Loire plume. Strong thermal stratification is the characteristic of summer conditions in this area of the Bay of Biscay (Lunven et al., 2005), and thin layers of the toxin producing dinoflagellate Dinophysis acuminata have been recorded (Gentien et al., 1995, Lunven et al., 2005). Whilst Dinophysis thin layers were not recorded during a survey carried out in July 2006 in the northeastern region of the Bay of Biscay, a high density thin layer of a microflagellate (haptophyte) was observed along the west coast of France. This study examines its vertical and horizontal distribution in relation to physical measurements of the water column. 


\section{Materials and Methods}

\section{Field sampling}

Observations were made between 6 - 22 July 2006 in the northeastern Bay of Biscay over an area bounded by the French coast with southern and western extremes $47^{\circ} 15^{\prime} \mathrm{N}$ and $4^{\circ} 46^{\prime} \mathrm{W}$ respectively (Figure 1). The first part of the survey (6 - 12 July 2006) sampled a grid of 37 stations (Figure 1a) in order to identify the presence of phytoplankton thin layers. In the second part (13 - 22 July 2006, Figure 1b) high resolution data and samples were collected from thin layers identified during the first leg. Throughout the entire survey, continuous underway measurements of sea surface (5-m) temperature, salinity and chlorophyll $a$ fluorescence were recorded at 30 second intervals using a thermosalinograph (Seabird SBE21) and flow through fluorometer (Turner Designs Model 10) in line with the pumped water supply. The ship's track followed the station numbers in Figure 1a sequentially. Between stations the ships speed was 6 and 12 knots which with a 30 second surface sampling interval, was equivalent to a measurement being taken every 0.09 $0.19 \mathrm{~km}$. Data were integrated into a data acquisition system along with positional, bathymetric and meteorological data. Weather conditions during the cruise were noted as being unusually warm with data from the ship's underway temperature record showing maximum values of air temperature increasing from $22.7^{\circ} \mathrm{C}$ to $31.6^{\circ} \mathrm{C}$ over the cruise. Sea conditions were extremely calm, with wind speeds averaging 11 knots over the entire survey. During the survey, three Argos satellite tracked drifter buoys were released (Table 1; Figure 1). The drifters were drogued at $15 \mathrm{~m}$ depth, deployed towards the start of the survey and tracked for its duration.

At most of the sampling stations vertical profiles of temperature, salinity and chlorophyll fluorescence were obtained using a pelagic profiler comprising a CTD (Seabird SBE 25) and an in situ fluorometer (Wetlabs, USA) which were interfaced with an in situ particle size analyser (Gentien et al., 1995). The 
exceptions were stations 49-56 when vertical phytoplankton net hauls only were taken. Profiled data were collected at a sampling rate of 8 samples per second, with a descent rate of the profiler of approximately $0.25 \mathrm{~m} \mathrm{~s}^{-1}$. Ship heave did not affect data output due to the exceptionally calm weather conditions experienced. The vertical attenuation coefficients for photosynthetically active radiation (PAR) were estimated from in situ measurements through an underwater irradiance sensor (Licor model 193) mounted and interfaced on the CTD. The attenuation coefficient was derived from the slope of the plot of the logarithm of PAR against depth between $5 \mathrm{~m}$ and the bottom of the surface mixed layer or, when present, the top of the sub-surface chlorophyll maximum. Water samples were routinely obtained at each station by pumping seawater through a hose, whose end was attached to the profiler. Otherwise, water samples were obtained from discrete depths using a bottle rosette mounted on the CTD frame. Sample depths were determined from the profiles of fluorescence and particle distribution. The standard sampling procedure involved samples being taken from within the surface mixed layer, at the pycnocline, at the particle and fluorescence maxima, below the pycnocline, within the bottom mixed layer and near the sea bed. Samples for inorganic nutrient analysis were taken from the CTD rosette bottles only. Samples for phytoplankton analysis were preserved in unacidified Lugol's Iodine and stored in $55 \mathrm{ml}$ cell culture bottles. At Station 42 (Figure 1b), water samples with high vertical resolution were obtained using a Fine Scale Sampler (FSS) (Lunven et al., 2005), which comprised fifteen 2-L Niskin water sampling bottles positioned $20 \mathrm{~cm}$ apart on a metal frame to which a CTD probe (SeaBird SBE19+) and an in situ fluorometer (WetLabs) were attached. An electromagnetic switch closed all fifteen water bottles simultaneously when the instrument spanned the required depth range.

During the second part of the survey, additional high resolution measurements of water column temperature, salinity and chlorophyll 
fluorescence were made by towing an undulating CTD with integrated fluorometer (Scanfish; Brown et al., 1996; Fernand, 1999) along the transects shown in Figure 1. This instrument was towed with a ship's speed of $3.0-4.0$ $\mathrm{m} \mathrm{s}^{-1}$ and achieved profiles from $4 \mathrm{~m}$ below the sea surface to within $5 \mathrm{~m}$ of the seabed with a horizontal resolution of approximately $400 \mathrm{~m}$. Data was collected at a scan rate of $25 \mathrm{~Hz}$. Visualisation of the data collected by Scanfish was carried out in Surfer (v7.02, Golden Software). A point Kriging gridding method was used to interpolate the data prior to contouring with $\mathrm{x}$ spacing $1.8 \mathrm{~km}$, y spacing $2 \mathrm{~m}$ for salinity to reduce noise, and with $\mathrm{x}$ spacing: $0.9 \mathrm{~km}$, y spacing: $0.9 \mathrm{~m}$ for density and fluorescence.

Periodic high resolution vertical profiles of current speeds were also obtained during the second leg in order to estimate the vertical profile of horizontal shear at locations where thin layers were observed. A high frequency (600 $\mathrm{kHz}$ ) Acoustic Doppler Current Profiler (ADCP) (RD Instruments) was mounted facing downwards on the CTD profiler frame at selected stations (Stations 43, 44, 58, 59, 60, 61, 62, 63, 64, 65, 66, 68 and 71, Figure 1b), and the profiler frame was suspended for 5-10 minute intervals at approximately $5 \mathrm{~m}$ at the end of the CTD upcast. Measurements of current magnitude and direction were determined at $0.5 \mathrm{~m}$ depth bins (30 pings per ensemble, $20 \mathrm{sec}$ ensemble interval) which effectively gave a depth profile over $20 \mathrm{~m}$ from which the vertical shear profile could be determined. For each station, up to 5 min of ADCP data was averaged and shear was calculated from the formula $\mathrm{S}^{2}=(\delta u / d z)^{2}+(\delta v / d z)^{2}$, where $\mathrm{S}$ is the total shear $\left(\mathrm{s}^{-2}\right)$, and $\delta u / d z$ and $\delta v / d z\left(\mathrm{~s}^{-1}\right)$ are the east and north velocity gradients respectively (Itsweire et al., 1989), accounting for ship's drift. Results were compared with the Brunt Väisälä frequency $\left(\mathrm{N}^{2}\right)$ calculated from the density profile of the equivalent CTD downcast; $\mathrm{N}^{2}$ estimates the strength of the vertical density gradient $\left(\mathrm{N}^{2}=\right.$ $\mathrm{g} / \rho(\mathrm{d} \rho / \mathrm{dz}))$, where $\mathrm{g}$ is acceleration due to gravity $\rho$ is the density $\left(\mathrm{kg} \mathrm{m}^{-3}\right)$ and $d \rho / d z$ the change in density with depth. Profiles of $N^{2}$ and shear $\left(S^{2}\right)$ 
were interpolated using a cubic spline and from these the Richardon number $\left(\mathrm{Ri}=\mathrm{N}^{2} / \mathrm{S}^{2}\right)$ could be calculated (Miles, 1963).

\section{Laboratory analyses}

Nutrient (nitrate and phosphate) samples were analysed in the laboratory using automated analysis (Technicon) following the methods in Aminot and Kerouel (2007).. Phytoplankton concentrations were measured using a modified Utermhöl's technique (McDermott and Raine, 2009). Cells were identified to genus and, where possible, species and cell densities were calculated. Multivariate analysis was carried out on the results using the software package VESPAN III (Malloch, 1995). This software provides a twoway indicator species analysis (TWINSPAN; (Hill, 1979), an analysis based on the concept that a group of samples which constitute a community type will have a corresponding group of species that characterise that type (i.e., indicator species). The data were transformed logarithmically, and unidentified nanoplanktonic $(<10 \mu \mathrm{m})$ flagellates were not included in the analysis, in order to reduce data noise.

Transmission electron microscopy was used to examine phytoplankton specimens. Water samples $(5 \mathrm{ml})$ were concentrated by centrifugation, rinsed and resuspended three times with distilled water to remove salt crystals and preservative. After gentle mixing of the cleaned material, a drop of sample was pipetted onto a formvar carbon coated 200 mesh copper grid. For observation of Pseudo-nitzschia species, the same procedure as described above was employed with vertical net haul samples. An additional step of acid washing $\left(65 \% \mathrm{HNO}_{3}\right)$ the cell frustules at $80^{\circ} \mathrm{C}$ for $30 \mathrm{~min}$ followed by further cleaning of the samples with distilled water (Cusack et al., 2004) was included before the samples were loaded onto the copper grids. All of the prepared grids were examined using a Hitachi 7000 transmission electron microscope. 


\section{Data analysis}

Descriptions of thin layers were based on Sullivan et al. (2009) where the first derivative of the fluorescence profile was used to define the upper and lower limits of the layer. Profiles of fluorescence were averaged into $1 \mathrm{~m}$ bins from which the first derivative was calculated. A minimum of 2 data points comprised each $1 \mathrm{~m}$ depth bin but up to 100 data points (derived from up to 400 data signals) were collected when the instruments were held at depth during sampling. The values representing $30 \%$ of the maximum and minimum derivative value, as the derivative curve returned towards zero, were defined as the vertical extremities of the layer. All available data points within these extremities were extracted and layer measurements were based upon them. Thin layers were defined by the criteria in GEOHAB (2008) as layers where the maximum fluorescence intensity is at least five times the background and the layer thickness at half the maximum intensity is less than $3 \mathrm{~m}$. 


\section{Results}

Temperature, Salinity and Stratification

Near surface measurements of temperature and salinity ranged from 14.6 to $23.9^{\circ} \mathrm{C}$ and 33.3 to 35.7 respectively. A subset (6-10 July 2006) of surface temperature and salinity is shown in Figure 2a, b). The lowest surface temperatures $\left(14.6^{\circ} \mathrm{C}\right)$ were along the southern coast of Brittany, inshore of Belle Îsle en Mer, a feature probably due to a combination of increased tidal mixing in shallower water columns and weak coastal upwelling which occurs during spring and summer under westerly wind conditions (Lazure and Jégou, 1998, Puillat et al., 2006). Average daily wind speed and direction were variable (SW-WNW; 7-14 knots) for the period (6-10 July) shown in Figure 1d. Offshore, surface temperatures increased and the maximum surface temperatures were observed at the southern perimeter of the survey area. The lowest salinity values were recorded close to the mouth of the Loire River where the signature of the river plume was apparent as a region of cooler, low salinity, surface water (Figure 2a, b). Two surface fronts were observed (Figure 2c). A rapid increase in surface temperatures and salinities indicated the location where the Loire River plume met coastal shelf waters. Further offshore, a small increase in surface salinity and decrease in surface temperature marked the boundary between coastal shelf waters and water with more oceanic characteristics.

Stratification of the water column was evident in the CTD record for virtually all the sampling locations. The exceptions were the shallow $(<20 \mathrm{~m})$ stations 22, 23 and 32. Figure 3 shows the ScanFish data record for salinity and density along sections running normal to the coastline. The temperature difference across the pycnocline was 6-7 deg C. A sub-surface saline (S>34.9) layer can be seen encroaching almost up to the coastline. Density gradients of $\delta \rho / \delta \mathrm{z}=0.25-0.3$ sigma-t $\mathrm{m}^{-1}$ were evident at the pycnocline which deepened from ca. $15 \mathrm{~m}$ to $25 \mathrm{~m}$ depth. 
Nutrients, irradiance and chlorophyll

Surface water was depleted in nutrients (nitrate and phosphate) at all stations, with $\mathrm{NO}_{3}$ levels consistently $<0.1 \mu \mathrm{M} \mathrm{Kg}{ }^{-1}$ and $\mathrm{PO}_{4}<0.071 \mu \mathrm{M} \mathrm{Kg}{ }^{-1}$. Significant nutrient levels ( $\left.>2 \mu \mathrm{M} \mathrm{NO}_{3} \mathrm{Kg}^{-1}\right)$ were present in the bottom mixed layer, where salinity was $>34.9$. Thus, there were minimal nutrient levels in the entire water column of the shallow stations 22 and $23(<0.11 \mu \mathrm{M}$ $\mathrm{NO}_{3} \mathrm{Kg}^{-1}$ ), yet at stations 8, 21, 24 and 34 nitrate levels were 2.2-5.4 $\mu \mathrm{M} \mathrm{Kg}^{-1}$, beneath the pycnocline located at about 7 (Stations 21, 24) and 15 (Stations 15, 16) metres depth. Further offshore, nutrient levels beneath the thermocline rose to 10 and $0.55 \mu \mathrm{M} \mathrm{Kg}^{-1}$ for $\mathrm{NO}_{3}$ and $\mathrm{PO}_{4}$ respectively. A plot of nitrate against salinity (Figure 4) clearly shows the mixing of water and nutrients between offshore and near coastal waters below the pycnocline.

Vertical attenuation coefficients of PAR were measured at several stations occupied during the day. Values of $0.08-0.09 \mathrm{~m}^{-1}$ were measured at stations 40, 41 and 44. More inshore, values of $0.12-0.15 \mathrm{~m}^{-1}$ were obtained at stations $17,18,19,25$ and 61 , whereas highest values between $0.20-0.23 \mathrm{~m}^{-1}$ were found at stations 26, 32 and 47 . these results imply a euphotic zone depth, defined as $1 \%$ surface irradiance level, of at least $20 \mathrm{~m}$.

It can be deduced from the distributions of salinity, nutrients and attenuation that nutrients were plentiful at and below $10-15 \mathrm{~m}$, approximating the depth of the pycnocline, at the inshore stations, and that these pycnocline depths were well within the euphotic zone.

An intense sub-surface chlorophyll maximum was present at the coastal stations, where measurable nitrate existed beneath the pycnocline. The subsurface chlorophyll maximum was a consistent feature of the water column of the study area, and can be seen along the Scanfish sections shown in Figure 3a. West of $3^{\circ} 10^{\prime}$ longitude in the section shown in Figure $3 \mathrm{a}$, the 
chlorophyll fluorescence values at the maximum were on average $8 \mathrm{mg} \mathrm{m}^{-3}$ (chlorophyll equivalents). Inshore of this, the fluorescence levels were higher with up to $32 \mathrm{mg}$ chl eq $\mathrm{m}^{-3}$.

Phytoplankton

Multivariate analysis (TWINSPAN) clustered phytoplankton populations, sampled at fluorescence maxima, into four types of communities, one offshore and three coastal (Figure 5a, b). The offshore cluster, which separated out at the first division in the analysis (Figure $5 b$ ) was dominated by a mixture of summer diatoms, mainly large ( $>3 \mu \mathrm{m}$ valve width) and small $(<3 \mu \mathrm{m}$ valve width) species of the diatom Pseudo-nitzschia spp., and a number of Chaetoceros spp., of which the most readily identifiable were $C$. danicus and $C$. debilis. Examination of the Pseudo-nitzschia cells by transmission electron microscopy showed that Pseudo-nitzschia pungens and P. multiseries were numerically dominant. Some small $(<20 \mu \mathrm{m})$ dinoflagellate species were also present here, in particular Gymnodinium spp., Prorocentrum dentatum and Heterocapsa cf. niei.

The next division separated the two groups (Groups B and C) of sampling stations found close to the coast from a cluster (Group D) of stations, which were located at the approximate boundary between the inshore and offshore stations. The two coastal clusters (B and C) were geographically distinct in that Group B comprised stations along the southern coast of Brittany towards the mouth of the River Loire while Group C stations were located from the mouth of the Loire River further south along the coastline. Both Groups B and D comprised a mixed assemblage of diatoms species. Pseudo-nitzschia spp. (predominately types with valve width $>3 \mu \mathrm{m}$, again, including $P$. multiseries and P. pungens) and Chaetoceros spp. shared a collective dominance with Leptocylindrus spp at the boundary group of stations (Group B). Inshore, Leptocylindrus spp. (L. danicus and L. minimus) were dominant in Group B 


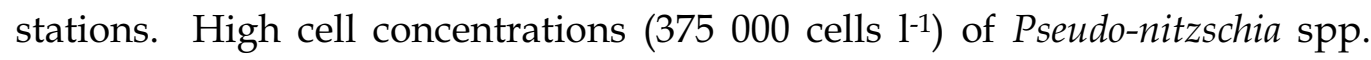
were observed at the Bay of Douarnenez (St 37).

At sampling stations in the proximity of the Vilaine and near the mouth of the Loire River there was some notable concentrations of Prorocentrum spp. (13 x $10^{3}$ cells $^{-1}$ ) and an unidentified haptophyte species (up to $1.5 \times 10^{6}$ cells $1^{-1}$ during leg 1). The phytoplankton composition of Group C was almost entirely associated with this haptophyte. Its numerical and biomass dominance in the coastal station samples was a prominant feature of the phytoplankton community observed during the survey. This organism was found particularly at stations near the mouth of the River Loire during both parts of the survey, reaching cell concentrations of up to $6 \times 10^{6}$ cells $1^{-1}$ (Figure 5c, d).

The haptophyte cells were spherical to ovoid in shape and ca. $20 \mu \mathrm{m}$ in diameter. The haptonema, visible under the light microscope, was approx. $2 / 3$ the length of the two flagella, which were of equal length $(12-15 \mu \mathrm{m})$ (Figure 6a, b). The flagella and haptonema arose close together. Examples of scale structure are shown in Figure 6c-g. Two types of ovoid to round scales were present in approximately equal numbers, with a size of $1.5 \times 1 \mu \mathrm{m}$ (Figure 6c). One type of scale was surrounded by a flat rim (ca $200 \mathrm{~nm}$ width) (Figure 6d). Both scale types had an interior structure comprised of microfibrils radiating from the centre of the scale on both the ventral and dorsal sides. A third spine scale (Figure 6f-g), which was considerably less abundant than the other two types, possessed a low raised rim of $200 \mathrm{~nm}$, and radiating microfibrils were only observed on the one side. These cell characteristics were similar to that of the genus Chrysochromulina yet unlike any previously described species (Ø. Moestrup, pers comm).

The focus of the haptophyte population was near the mouth of the Loire (Stations 21 and 31). The bloom was observed below the pycnocline over the entire survey in this region with cell densities of 1-6 $\times 10^{6}$ cells $^{-1}$ (Figure 7). 
The vertical profile of the haptophyte was well resolved through deployment of the Fine Scale Sampler (FSS) at station 42 on 15 July (Figure 7c), where up to $5.3 \times 10^{6}$ cells $^{-1}$ were observed, mirroring the fluorescence signal. It can be seen that the haptophyte population was restricted to the bottom mixed layer at these inshore stations. Away from the coast, cell concentrations were reduced suggesting a spreading of cells away from the focal point of the population.

The Scanfish fluorescence plots (Figure 3) and cell densities (Figure 5) showed that the haptophyte was restricted to within ca. $35 \mathrm{~km}$ from the coastline. Its distribution suggested that the bloom had originated at the coast and spread seaward along the pycnocline: cell density maxima close to the coast had increased by a factor of four between the first and second part of the survey (an approximate time span of 7-10 days), while further seaward the increase in cell concentrations was of the order of 15 .

Thin layers and horizontal shear

A total of 17 out of 64 vertical profiles showed a thin fluorescence layer. The median thickness of the layers was $1.8 \mathrm{~m}$, with chlorophyll maxima up to 22 $\mathrm{mg} \mathrm{m}^{-3} \mathrm{chl}$-a equivalents. All were associated with density discontinuities and 14 were in the top $20 \mathrm{~m}$ of the water column, within the seasonal pycnocline. The unidentified haptophyte dominated 13 of the 17 thin layers (Stations 17, $18,21,24,25,33,42,47,59,60,61,68$ and 79, observed. The other four were comprised of a mixed assemblage of diatom species, two with some haptophyte (Stations 7 and 8; Figure 1a), one predominantly Leptocylindrus (Station 26; Figure 1a), and the other thin layer at Station 43 (Figure 1b) was dominated by Pseudo-nitzschia pungens.

The majority of the thin layers were observed west of the mouth of the Loire River, and it was here that the highest shear values of 3-7 $\times 10^{-2} \mathrm{~s}^{-1}$ were observed within the top $20 \mathrm{~m}$ of the water column. At sampling stations along the southern coast of Brittany observed values of shear were lower $(<3$ 
$\left.x 10^{-2} \mathrm{~s}^{-1}\right)$. Shear measurements were taken at six sampling stations where thin layers were observed (Stations 43, 59, 60, 61, 62 and 68) containing high cell densities of the haptophyte. A comparison of the profiles showed that the thin layers of fluorescence were associated with a shear minimum, sandwiched between two shear maxima (Figure 8; stations 59,60). This layer, co-incident with a shear minimum, was stable judging by the high Richardson number $(\mathrm{Ri}>0.25)$ at the depth of the layer. Figure 8 also gives a contrasting example of a wider, less intense, chlorophyll maxima which was observed further offshore at station 71 (Figure 1), Although the water column at the depth of the layer was stable $(\mathrm{Ri}>0.25)$, the fluorescence maximum was not associated with the region of maximum shear and a thin layer was not evident. 


\section{Horizontal diffusion and advection model}

Stations where the haptophyte were observed were designated into three groups based on the associated water salinity. An inshore group (Group I) was characterised by low surface salinities of $33.3-33.8$ and salinity values of 35 - 35.1 towards the seabed. An offshore group of stations, Group III, were located west of a surface salinity front at $2^{\circ} 50^{\prime} \mathrm{W}$ on Leg 1 , Figure $1 \mathrm{~d}$ ) or $2^{\circ}$ $55^{\prime} \mathrm{W}$ on Leg 2 (not shown). These stations had surface salinity values $>34.8$ and bottom salinity values exceeding 35.5. Stations in between (Group II) had significantly higher surface and bottom values than Group I (34.4-34.8 and up to 35.4 respectively). Distinguishing between these groups provided the framework for estimating the rate of change in cell density between the two parts of the survey.

The advection - diffusion (mass balance) equation (1) was used to determine the rate of change in concentration of a constituent of sea water.

$$
\delta C / \delta t=K_{x}\left(\delta^{2} C / \delta x^{2}\right)-U_{x}(\delta C / \delta x)+\mu C-K_{z}\left(\delta^{2} C / \delta z^{2}\right)
$$

where the rate of change of cell density $(\delta C / \delta t)$ is equal to the horizontal diffusive flux $\left(K_{x}\left(\delta^{2} C / \delta x^{2}\right)\right)$, minus any horizontal advection $\left(U_{x}(\delta C / \delta x)\right)$, plus any in situ production $(\mu C)$, less any loss terms associated with vertical diffusion $\left(K_{z}\left(\delta^{2} C / \delta z^{2}\right)\right)$.

The change in cell concentration with time $(\delta C / d t)$. At the location of Group II, the population had increased by a mean value of 300,000 cells $1^{-1}$ cells in approximately 8.5 days (Table 2 ). Thus $\delta C / \delta t=0.41 \times 10^{3}$ cells $\mathrm{m}^{-3} \mathrm{~s}^{-1}$ :

Advection $\left(U_{x}(\delta C / \delta x)\right)$. The non-tidal currents in the region were approximately $4.2 \mathrm{~km} \mathrm{~d}^{-1}$. All three drifter buoys, drogued at $15 \mathrm{~m}$, maintained a general southeastwards track, from which the residual current was estimated (Figure 1). Current measurements from ADCP deployments were significantly greater than this due to tidal influences, as tidal currents 
are reported as an order of magnitude higher than residual advection (Service Hydrographique et Océanographique de la Marine, 2005).

The advective flux of cells is the horizontal velocity $\left(U_{x}\right)$ component multiplied by the concentration gradient $(\delta C / \delta x)$. The term $\delta C / \delta x$ was calculated for each leg of the survey (Leg $1=14 \times 10^{3}$ cells m$^{-3} \mathrm{~m}^{-1} ;$ Leg $2=53$ $\times 10^{3}$ cells $\mathrm{m}^{-3} \mathrm{~m}^{-1}$, see Table 2) and the mean $34 \times 10^{3}$ cells $\mathrm{m}^{-4}$ was used in subsequent calculations. With a $U_{x}$ of $0.05 \mathrm{~m} \mathrm{~s}^{-1}\left(=4.2 \mathrm{~km} \mathrm{~d}^{-1}\right)$ this gives an estimate of advective flux of $1.7 \times 10^{3}$ cells $\mathrm{m}^{-3} \mathrm{~s}^{-1}$

Growth $(\mu C)$. The rate of change of cell density $(\delta C / \delta t)$ is equal to $\mu \mathrm{C}$ where $\mu$ is the specific growth rate and $C$ the cell concentration. No measurements of $\mu$ were attempted during the survey. Values in the literature range from 0.2$0.8 \mathrm{~d}^{-1}$ (Maestrini and Graneli, 1991) for similar species in the genus Chrysochromulina. In the first instance, a value of $0.6 \mathrm{~d}^{-1}$ was applied $(=6.9 \mathrm{x}$ $\left.10^{-6} \mathrm{~s}^{-1}\right)$, as this approximates the growth rate during haptophyte blooms; microscopy showed that the population was active and in healthy condition. A value of $C$ of $390 \times 10^{6}$ cells $\mathrm{m}^{-3}$ was identified as the mid point concentration value between the Leg 1 and Leg 2 averages in observed Group II cell concentrations (Table 2). This results in a $\mu C$ value of $\left(3.9 \times 10^{8}\right) \times(6.9 \times$ $\left.10^{-6}\right)=2.7 \times 10^{3}$ cells m$^{-3} \mathrm{~s}^{-1}$

Vertical diffusion $\left(K_{z}\left(\delta^{2} C / \delta z^{2}\right)\right)$. The vertical flux, $\left(K_{z}\left(\delta^{2} C / \delta z^{2}\right)\right)$, is derived from the coefficient of turbulent diffusivity (rather than simply the vertical diffusion coefficient) $\left(K_{z}\right)$ and gradients in vertical population $\left.\left(\delta^{2} C / \delta z^{2}\right)\right)$. Derivation of the value for $\left(K_{z}\right)$ can be achieved in two ways. It can either be determined from the vertical heat flux (e.g., Tett et al., 1986), or the degree of overturn within the thermocline (Thorpe, 2007). Both methods require knowledge of the temperature profile, but the latter method requires high resolution measurements from near the pycnocline. Due to the nature of sampling, the CTD was held in or near the thermocline for extended periods at several depths on the upcast, and so measurements of overturn were 
hampered due to the heterogeneity of the temperature-depth values, mainly due to the influence of internal waves. On the downcast, there was not a satisfactory resolution in the data. Estimates of $K_{z}$ were therefore based on heat flux, and due to similarity in the region to the conditions described in Tett et al. (1986) for temperate waters, a downwards heat flux $\left(\varphi_{H}\right)$ of $700 \mathrm{kcal}$ $\mathrm{m}^{-2} \mathrm{~d}^{-1}$ was applied. Given the equation:

$$
K_{z}=\varphi_{H} /(\rho c(\delta t / \delta z))
$$

we applied a density $(\rho)$ value of $1026 \mathrm{~kg} \mathrm{~m}^{-3}$, and $1 \mathrm{kcal} \mathrm{kg}^{-1}$ for $c$, the specific heat, to the observed temperature gradient $(\delta t / \delta z$, with a resolution of $1 \mathrm{~m})$. For stations in Group II, this gave estimates of $K_{z}$ across the thermocline of 0.5 $-2.5 \times 10^{-5} \mathrm{~m}^{2} \mathrm{~s}^{-1}$

Group II stations were used to estimate the term $\left(\delta^{2} C / \delta z^{2}\right)$ from the vertical distributions of the haptophyte population. - These stations had relatively sharp vertical peaks in fluorescence with corresponding high cell density maxima (see e.g. station 60, Figure 6a). This contrasted with Group III where cell concentrations were generally low and associated with thicker fluorescence peaks, and Group I where the haptophyte cell maxima were confined to the bottom mixed layer. Station 62, which was located at the approximate geographic mid-point location of the Group II station cluster (Figure 1b, Table 2), was taken as a representative profile of cell concentrations for vertical fluxes. The above method of estimating $\delta^{2} C / \delta z^{2}$ may not, however, fully account for variability within the vertical structure of the water column at individual sampling locations. One drawback in using this approach is that the vertical population gradient is directly proportional to the vertical flux if a constant $K_{z}$ is applied at every station. However, reduced values in $K_{z}$ were generally accompanied by higher absolute concentrations at the cell maxima, minimising the errors arising from biological sampling and processing. Reduced vertical mixing limited the vertical migration of cells and hence the concentration of cells within the 
layer. Estimated values of the change in cell concentrations between samples taken above and below the population maximum at station 62 (Table 3) were $51 \times 10^{6}\left(\right.$ cells $\left.\mathrm{m}^{-3}\right) \mathrm{m}^{-2}$ and $22 \times 10^{6}\left(\right.$ cells $\left.\left.\mathrm{m}^{-3}\right) \mathrm{m}^{-2}\right)$ respectively. The upward and downward vertical fluxes were estimated from

$$
\begin{array}{ll}
K_{z}\left(\delta^{2} \mathrm{C} / \delta z^{2}\right) \text { up }=\left(1.2 \times 10^{-5}\right) \times\left(51 \times 10^{6}\right)= & 0.61 \times 10^{3} \text { cells } \mathrm{m}^{-3} \mathrm{~s}^{-1} \\
K_{z}\left(\delta^{2} \mathrm{C} / \delta z^{2}\right) \text { down }=\left(1.2 \times 10^{-5}\right) \times\left(22 \times 10^{6}\right)= & 0.26 \times 10^{3} \text { cells } \mathrm{m}^{-3} \mathrm{~s}^{-1}
\end{array}
$$

which were then combined to gain a total for $K_{z}\left(\delta^{2} \mathrm{C} / \delta z^{2}\right)$ of $0.87 \times 10^{3}$ cells $\mathrm{m}^{-3}$ $\mathrm{s}^{-1}$

Horizontal diffusion $\left(K_{x}\left(\delta^{2} C / \delta x^{2}\right)\right)$.

$K_{x}\left(\delta^{2} C / \delta x^{2}\right)$ is the horizontal diffusive flux where $K_{x}$ is the horizontal diffusion coefficient, which expresses the effective dispersal of the velocity field. The term $\delta^{2} C / \delta x^{2}$ is the rate of change in the concentration gradient of the population along the $\mathrm{x}$ axis (seaward). The rate of change of cells with distance offshore $(\delta C / \delta x)$ was estimated between Groups for both legs of the survey (see Table 2). A value for $\delta^{2} C / \delta x^{2}$ was then calculated from the results (Leg 1: $0.78\left(\right.$ cells $\left.\left.\mathrm{m}^{-3}\right) \mathrm{m}^{-1}\right) \mathrm{m}^{-1}$, Leg 2: $2.1\left(\left(\right.\right.$ cells $\left.\left.\mathrm{m}^{-3}\right) \mathrm{m}^{-1}\right) \mathrm{m}^{-1}$. The average of both legs $\left(1.4\left(\left(\right.\right.\right.$ cells $\left.\left.\left.\mathrm{m}^{-3}\right) \mathrm{m}^{-1}\right) \mathrm{m}^{-1}\right)$ was applied in the mass balance equation which was used to achieve a value for $K_{x}$. Simple substitution of the calculated values for advection, growth and vertical diffusion into the mass balance equation (1) allows an estimate of the remaining unknown term $K_{x}$. These are summarised in Table 4 from which it was calculated that $K_{x}=90 \mathrm{~m}^{2}$ $\mathrm{s}^{-1}$.

The operational scales for horizontal diffusion, horizontal advection, vertical diffusion and growth are all of approximately the same order $\left(10^{3}\right.$ cells $\mathrm{m}^{-3} \mathrm{~s}^{-}$ 1). This implies that all of these processes have potentially a similar governing influence on the spread of the population and no one process dominated. 
It is difficult to determine the errors on the values obtained in Table 4 . These could derive from the averaging (and assumptions) used above. However, the two variables with the greatest potential for error are the estimates of cell growth rate and horizontal dispersal. Take, for example, the value used for growth, which relies on the physiological state of the organism. If the lower end of the range given by Maestrini and Graneli (1991) is applied, an increase in the value of the horizontal diffusion coefficient by nearly two orders of magnitude would be needed to balance observations. Alternatively, at the high end of the range, with a growth rate of $0.8 \mathrm{~d}^{-1}$, growth would become the governing variable and the horizontal diffusion coefficient would be rendered insignificant. Models of phytoplankton growth are always highly sensitive to the magnitude of the growth rate chosen (e.g., Stock et al., 2005). Haptophytes are capable of explosive growth leading to intense, virtually monospecific blooms (Smayda, 2006) such as the one described here. Models of harmful algal blooms generally require a minimum growth rate of $0.5 \mathrm{~d}^{-1}$, regardless of the species chosen, in order to become established (McGillicuddy et al., 2005; Ni Rathaille, 2007).

When considering horizontal dispersal, the rate of change of the concentration of the population offshore $\left(\delta^{2} C / \delta x^{2}\right)$ was derived from averaged values between the first and second leg of the survey. When these values were applied individually estimates for $K_{x}$ of 165 and $62 \mathrm{~m}^{2} \mathrm{~s}^{-1}$ were achieved respectively. These values are however of a similar order to that calculated from the average $\left(\delta^{2} C / \delta x^{2}\right)$.

Another method of estimating horizontal diffusion is to relate the dispersion coefficient, $K_{x}$, to the statistical properties of the concentration curve distribution (Fischer et al., 1979). Horizontal dispersal can be estimated from the changes in the variance $\left(\sigma^{2}\right)$ in the population with time $(t)$. From the properties of the normal (Gaussian) distribution, $2 K_{x} t=\sigma^{2}$ and $K_{x}$ can be calculated from $K_{x}=0.5 \times\left(\delta \sigma^{2} / \delta t\right)$. 
This was carried out using the observations outlined in Table 2 for Leg 2 of the survey. The variance can be estimated from the sum of the squared differences between the mean and actual distance of each population cell (Table 5)

For $t=734 \times 10^{3} \mathrm{~s}^{-1}$ (8.5 days; Table 2)), $K_{x}$ can be derived from substitution into equation (2) which results in a value of $106 \mathrm{~m}^{2} \mathrm{~s}^{-1}$. No growth, horizontal advection or vertical diffusion are included in this term so this should be an underestimate. However, it is of the same order as the value derived from the mass balance equation for the population. 


\section{Discussion}

Marine haptophytes often occur in high cell concentrations, forming virtually monospecific blooms (Edvardsen and Paasche, 1998). These blooms have been reviewed in detail due to their potential toxicity and consequent economic damage to finfish culture (see Smayda, 2006). Probably the most studied are the coccolithophorid Emiliania huxleyi, which blooms in late spring and is readily visible through ocean colour remote sensing due to high reflectance, and the genus Chrysochromulina. Chrysochromulina is considered to have a cosmopolitan distribution, with members of the genus observed to be regularly present in the phytoplankton worldwide (Dahl, 2005). Although, it is usually found in moderate cell concentrations $\left(10^{3}-10^{5}\right.$ cells $\mathrm{l}^{-1}$; Edvardsen and Paasche, 1998), cell numbers can increase very rapidly, with immense blooms occurring in North Atlantic and Scandanavian waters (Edvardsen and Paasche, 1998; Dahl 2005). Although blooms have occurred without causing harm, it is suspected that all species of Chrysochromulina are potential toxin producers (Edvardsen, 2002). Historically, two exceptional toxic blooms of Chrysochromulina have been documented for Norwegian coastal waters. The occurrence of a bloom of $C$. polylepis within the Kattegat and Skagerrak, ocean channels between Norway, Sweden and Denmark, during April and May 1988 was described by Maestrini and Graneli (1991). In the later stages of the bloom, maximum cell concentrations reached $8 \times 10^{7}$ cells $\mathrm{l}^{-1}$ within a thin layer at the pycnocline (Dahl, 1989). A large bloom (3-5 $\mathrm{x}$

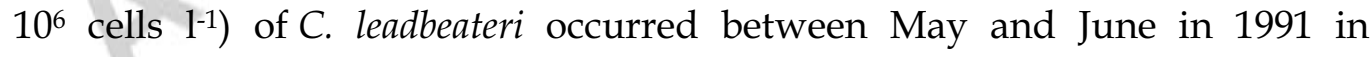
the Ofotfjord-Vestford region of Norway causing mass mortality of caged finfish (Aune et al., 1992). The frequency and intensity of harmful algal blooms, including blooms of new species, are increasing globally. The increase in the frequency of immense haptophyte blooms has been noted as a serious concern for aquaculture systems (Hallegraeff, 2003).

This paper presents observations of a thin layer of a haptophyte species, which bloomed in coastal waters of northwestern France. Although as yet 
unidentified, the species had a structure closely linked to Chrysochromulina. The organism was a consistent feature of an bloom extending some $35 \mathrm{~km}$ offshore along the coast from the Bay of Vilaine down to at least $46^{\circ} \mathrm{N}$. The nutrient, salinity and chlorophyll distributions suggest that the bloom had originated inshore, utilising nutrient that had mixed shorewards below the thermocline. The bloom, which was advecting southeastwards along the Bay of Biscay coast, was most intense in the shallow waters off the Loire estuary, where it was present underneath the estuarine plume. Its intensity and maintenance were promoted by both the shallowness of the environment (the depth range 7-25 m) allowing adequate irradiance and the enhanced nutrient levels underneath the plume which were mixing in from offshore in the bottom mixed layer. The influence of the Loire plume in promoting the bloom through riverine nutrient input was therefore negligible. Over the period the observations were made, the bloom increased in cell numbers and was dispersing westwards along the seasonal pycnocline. As the majority of subsurface fluorescence peaks observed were due to the presence of the haptophyte species, it was possible to identify its distribution and collect water samples of the haptophyte bloom.

During the survey, the bloom extended west $30-40 \mathrm{~km}$ away from the coast in a thin layer of thickness of only $2 \mathrm{~m}$. The depth of this layer adhered to the depth of the pycnocline, which maintained a constant height above the seabed, presumably caused by the control of tidal mixing on the depth of the bottom mixed layer. The argument for dispersal seawards, as opposed to in situ growth alone in the thin layer, was derived from the observation that, offshore, the population had increased proportionately far more than nearshore. Light conditions were inferior offshore where the pycnocline was deeper, encouraging higher growth and population increase inshore. Similarity in the seawater density where the sub-surface layer was found along transects normal to the coast also supports the idea of offshore spreading. 
Several mechanisms maintain sub-surface thin layers. A broad mix of biological and physical factors have been suggested which include migration, differential growth and grazing, aggregation, heterogeneity in vertical dispersion rates and shear (summarised by Franks, 1995; Donaghay and Osborn, 1997). In reality, it is ultimately a combination of processes which impose a driving force on layer dynamics (Birch et al., 2008). It is generally proposed that thin layers are stable if the associated Richardson number (Ri) is greater than 0.25 (Dekshenieks et al., 2001; McManus et al., 2005), and are less likely to break down due to turbulence. Based on this criterion, the Ri estimated for the depth of the thin layer implied a high degree of stability for the haptophyte population. Comparable stabilities were found all along the layer, which extended up to approximately $35 \mathrm{~km}$ offshore. These results reinforce the requirement for high resolution sampling technologies to allow quantification of thin layer processes.

The narrowness of the thin layers in the Bay of Biscay was remarkable considering that their thickness was substantially less than that of the seasonal pycnocline. As is often the case in seasonally stratified water columns (Hanson and Donaghay, 1998, Osborn, 1998), the 'seasonal pycnocline' in the Bay of Biscay comprised a series of density discontinuities. The haptophyte layer was associated with a depth interval between two density steps. Complementary measurements of currents made at similar scales to the fine structure in the pycnocline showed the expected result that vertical gradients in density coincided with strongest shear. The corresponding fine structure in the vertical distribution of horizontal shear revealed the haptophyte population lying between two shear maxima. It is concluded that shear had the greatest influence in controlling the width of the haptophyte thin layer. The general hypothesis that plankton distributions are strongly influenced by the vertical distribution of horizontal shear was also evident for stations where diatoms predominated in the plankton. 
Non-tidal currents in the study region were approximately $4.2 \mathrm{~km} \mathrm{~d}^{-1}(\sim 5 \mathrm{~cm}$ $\left.\mathrm{s}^{-1}\right)$. This is an order of magnitude lower than the tidal currents recorded when measuring vertical shear and noted for the locality (Alvarez Fanjul et al., 1997). The shear, which appeared to be restraining the haptophyte population in the thin layer, was therefore a direct result of the action of tidal currents in a stratified water column. Physical processes such as shear have demonstrated an ability to drive phytoplankton heterogeneity in both vertical and horizontal dimensions (Franks 1995, Stacey et al., 2007, Birch et al., 2008). Franks (1995) described a mechanism for thin layer formation by straining as a result of shear generated by internal waves. The model of Franks demonstrated tilting and stretching of a patch of phytoplankton along an isopycnal into a thin layer. The extent of the patch depended on the strength of the shear and the along isopycnal scale. The same mechanism of straining was analysed by Birch et al. (2008) for vertically sheared horizontal currents. Field observations of sheared flow as a result of processes at eddies, fronts and intrusions (Ryan et al., 2008, Johnston et al., 2009) have demonstrated similar results. In the above mentioned field studies high shear correlated well with the locations of thin layers, and in the case of Ryan et al. (2008) peaks in shear were associated with the centre of each layer. In contrast, during this study, thin layers were found at a shear minimum, between two maxima. The narrow vertical extent of the layer may have resulted from thinning by the shear above and below the layer as observed by Johnston et al. (2009). Other biological or environmental factors however have the opportunity to assume control and ultimately result in the survival or persistence of a thin layer (Donaghay and Osborn, 1997). For example, Stacey et al. (2007) proposed that cell swimming and buoyancy could counteract the physical dispersal resulting from the strain of the vertical velocity shear. Durham et al. (2009) suggested a mechanism termed "gyrotactic trapping" whereby swimming cells become disorientated by the effects of shear and as a consequence aggregate within a thin layer. The survival of a population within a thin layer can depend on factors including growth conditions, cell 
encounter rates, chemical signals, triggers and other modifications whereby species can gain advantage for example through enhanced nutrient uptake or altering the viscous properties of the surrounding seawater (Gentien et al., 2005). In this instance, we contend that the thin layer was initially caused by passive particle behaviour of the bloom as it spread westwards along its isopycnal. The general alongshore direction of residual (non-tidal) currents meant that this organism extended in high concentration over a wide, albeit coastal, area. The high cell density, broad fluorescence layers associated with this bloom occurring inshore were transformed into a sharp narrow gradient. The thin nature of this sub-surface layer resulted from the action of shear immediately above and below it.

Rates of horizontal dispersion at both small scale and larger scale have been measured by dye release experiments (Okubo, 1971) in both coastal and oceanic seas. The rates typically scale linearly with length and time due to the incorporation of different advective or pseudo-dispersive processes such as eddies. For the length scales considered here of $38 \mathrm{~km}$ and $76 \mathrm{~km}$ published values from a range of studies in the North Sea and North Atlantic are around $40-75 \mathrm{~m}^{2} \mathrm{~s}^{-1}$ respectively (Okubo, 1971). The derived value from the data presented here of $\sim 100 \mathrm{~m}^{2} \mathrm{~s}^{-1}$ is therefore consistent with these observations, although slightly higher. This could be due either to the presence of specific eddies in the region (e.g., Xie et al., 2007) or more likely to small differences in growth rate which can not be quantified from the measurements taken during the survey.

Seasonal stratification in the Bay of Biscay is favourable to the development of dinoflagellate populations between May and August (Gailhard et al., 2002). This is an important consideration when toxic or otherwise harmful species such as Dinophysis and Karenia mikimotoi have been observed in thin layers in these regions and elsewhere (Gentien et al., 2005; Lunven et al., 2005). The distribution of the microflagellate within a thin layer observed in this study along the coast of western France is not unlike that of the potentially harmful 
dinoflagellate Karenia mikimotoi. The growth and distribution of this species has been modeled successfully, showing sub-surface maxima developing at depths of minimum shear stress (Loyer et al. 2001). While low shear stress gives a competitive advantage to some species such as Karenia (see Loyer et al., 2001), with the haptophyte population being sandwiched between two high shear layers we contend that physical controls are defining the layer rather than behavioural processes such as preferential growth in low shear (turbulent) environments, noted for microflagellates, or avoidance mechanisms.

The distribution of Dinophysis and Karenia around northwestern France have been interpreted, and successfully modelled, in terms of regional physical structures such as gyres and coastal jets (Xie et al., 2007; Vanhoutte-Brunier et al., 2008). Both types of structures are perceived as ones which can horizontally contain the size of the patch of the harmful population. The one dimensional investigation implemented in this study may be limited by the horizontal sampling resolution, but has demonstrated the extent of horizontal spreading that can occur in the region should similar containment not be present. 


\section{Acknowledgements}

This work was funded through the European Commission (GOCE-CT-2005003932 HABIT) and the Irish Research Council for Science Engineering and Technology. The authors would like to acknowledge the assistance of the captain and crew of the R.V Thalassa. Special thanks to colleagues from NUI Galway, IEO Vigo Spain, CEFAS UK and IFREMER Brest for their assistance with field studies. 


\section{References}

Alvarez Fanjul, E., Pérez Gómez, B., and Rodríguez Sánchez-Arévalo, I. 1997. A description of the tides in the Eastern North Atlantic. Prog. Oceanogr. $40,217-244$.

Aminot A, Kerouel R., 2007. Dosage automatique des nutriments dans les eaux marines: méthodes en flux continu. Editions Ifremer, Paris. 187pp.

Birch, D.A., Young, W.R., and Franks, P.J.S., 2008. Thin layers of phytoplankton: Formation by shear and death by diffusion. Deep Sea Res. Pt 1 55(3), 277-295.

Bjørnsen, P.K., Nielsen, T.G., 1991. Decimeter scale heterogeneity in the plankton during a pycnocline bloom of Gyrodinium aureolum. Mar. Ecol. Prog. Ser. 73, 263-267.

Brown, J., Fernand, L., Hill, A.E., 1996. Scanfish: high performance towed undulator. Sea Tech. 37, 23-28.

Cowles, T.J., 2004. Thin layers of plankton: physical and biological interactions on the small scale, in: Seuront, L., Strutton P. (Eds.), Handbook of Scaling Methods in Aquatic Science, CRC Press, pp.31-49.

Cusack, C.K., Raine, R., Patching, J.P., 2004. Occurrence of species from the genus Pseudo-nitzschia Perragallo in Irish waters. Biol. Environ. 104B(1), $55-74$.

Dahl, E., Bagøien, E., Edvardsen, B., Stenseth, N.C., 2005. The dynamics of Chrysochromulina species in the Skagerrak in relation to environmental conditions, J. Sea Res. 54(1) 15-24.

Dekshenieks, M.M., Donaghay, P.L., Sullivan, J.M., Rines, J.E.B., Osborn, T.R., Twardowski, M.S., 2001. Temporal and spatial occurrence of thin 
phytoplankton layers in relation to physical processes. Mar. Ecol. Prog. Ser. 223, 61-71.

Donaghay, P.L., Osborn, T.R., 1997. Towards a theory of biological-physical control of harmful algal bloom dynamics and impacts. Limnol. Oceanogr. $42(5(2)), 1238-1296$.

Donaghay, P.L., Rines, H.M., Sieburth, J.M., 1992. Simultaneous sampling of fine scale biological, chemical and physical structure in stratified waters. Archiv. Hydrobiol. 36, 97-108.

Durham, W.M., Stocker, R., 2012. Thin Phytoplankton Layers: Characteristics, Mechanisms, and Consequences. Ann. Rev. Mar. Sci. 4,177-207.

Durham, W.M., Kessler, J.O., Stocker, R., 2009. Disruption of vertical motility by shear triggers formation of thin phytoplankton layers. Science. 323, 1067-1070.

Edvardsen, B., 2002. Life cycle strategies in the Haptophyte genera Chrysochromulina and Prymnesium, in: Garcés, E., Zingone,A., Montresor, M., Reguera, B., Dale, B. (Eds.), LIFEHAB: Life Histories of Microalgal Species Causing Harmful Blooms. Research in Enclosed Sea Series 12, European Commission EUR 20361, Luxembourg, pp. 67-70.

Edvardsen, B. and Paasche, E., 1998. Bloom dynamics and physiology of Prymnesium and Chrysochromulina, in: Anderson, D.M., Cembella, A.D., Hallegraeff, G.M. (Eds.), Physiological Ecology of Harmful Algal Blooms, NATO ASI series, Series G, Ecological Sciences nº 41, Springer-Verlag, Berlin, pp. 193-208

Eikrem, W., Throndsen, J., 1993. Toxic prymnesiophytes identified from Norwegian coastal waters, in: Smayda, T.J., Shimizu, Y. (Eds.) In Toxic Phytoplankton Blooms in the Sea, Elsevier Science, Amsterdam, pp. 687692. 
Farrell, H., Gentien, P., Fernand, L., Lunven, M., Reguera, B., González-Gil, S., Raine, R., 2012. Scales characterising a high density thin layer of Dinophysis acuta Ehrenberg and its transport within a coastal jet. Harmful Algae. 15, 36-46.

Fernand, L., 1999. High resolution observations of the velocity field and thermohaline structure of the western Irish Sea gyre. Ph.D Thesis, University of Wales, Bangor.

Fischer, H.B., List, J.E., Koh, R.C.Y., Imberger, J., Brooks, N.H., 1979. Mixing in Inland and Coastal Waters. Academic Press. New York, NY.

Franks, P.J.S., 1995. Thin layers of phytoplankton: a model of formation by near inertial wave shear. Deep Sea Res. Pt 1. 42(1), 75-91.

Gailhard, I., Gros, Ph., Durbec, J.P., Beliaeff, B., Belin, C., Nézan, E., Lassus, P., 2002. Variability patterns of microphytoplankton communities along the French coasts. Mar. Ecol. Prog. Ser. 250: 297-309, 2003

Gentien, P., Lunven, M., Lehaître, M. and Duvent, J.L., 1995. In-situ depth profiling of particle sizes. Deep Sea Res. Pt 1 42(8), 1297- 1312.

Gentien, P., Donaghay, P.L., Hidekatsu, Y., Raine, R., Reguera, B. and Osborn, T.R., 2005. Harmful algal blooms in stratified environments. Oceanography. 18(2), 172-183.

GEOHAB. 2008. Global Ecology and Oceanography of Harmful Algal Blooms, GEOHAB Core Research Project: HABs in Stratified Systems. Gentien, P., Reguera, B., Yamazaki, H., Fernand, L., Berdalet, E., Raine, R. (Eds.) IOC and SCOR, Paris, France and Newark, Delaware, USA, 59pp.

Hallegraeff, G.M., 2003. Harmful algal blooms: a global overview, in: Manual on Harmful Marine Microalgae, Hallegraeff, G.M., Anderson, D.M., 
Cembella, A.D (Eds.), IOC Manuals and Guides No. 33 UNESCO, Paris, pp.1-22.

Hanson, A.K.. Donaghay, P.L., 1998. Micro- to fine-scale chemical gradients and layers. Oceanography 11(1), 10-17.

Hill, M.O., 1979. TWINSPAN: A FORTRAN Program for Arranging Multivariate Data in an Ordered Two-Way Table by Classification of the Individuals and Attributes. Cornell University, Ecology and Systematics Publications. Cornell University, Ithaca, NY.

Kononen, K., Huttunen, M., Hallfors, S., Gentien, P., Lunven, M., Huttula, T., Laanemets, J., Lilover, M., Pavelson, J., Stips, A., 2003. Development of a deep chlorophyll maximum of Heterocapsa triquetra Ehrenb. at the entrance to the Gulf of Finland. Limnol. Oceanogr. 48(2), 594-607.

Loyer, S., Lazure, P., Gentien, P., Ménesguen, A., 2001. Modelling of Gymnodinium mikimotoi blooms along the French Atlantic coast: geographical and vertical distributions. Hydroécol. Appl.13, 57-76

Lunven M., Guillaud, J.F., Youenou, A., Crassous, M-P., Berric, R., Le Gall, E., Kérouel, R., Labry, C., and Aminot, A. 2005 Nutrient and phytoplankton distribution in the Loire river plume (Bay of Biscay, France) resolved by a new Fine Scale Sampler. Estuar. Coast. Shelf Sci. 65, 94-108.

Maestrini, S.Y. and Granéli, E., 1991. Environmental conditions and ecophysiological mechanisms which led to the 1988 Chrysochromulina polylepis bloom: An hypothesis. Oceanol. Acta. 14(4), 397-413.

Malloch, A.J.C., 1995. VESPAN III A Computer Package to Handle and Analyse Multivariate and Species Distribution Data. University of Lancaster. 
McGillicuddy, D.J., Anderson, D.M, Lynch, D.R., Townsend, D.W., 2005. Mechanisms regulating large-scale seasonal fluctuations in Alexandrium fundyense populations in the Gulf of Maine: Results from a physicalbiological model. Deep Sea Res. II, 52, 2698-2714.

McDermott, G., Raine, R., 2009. Settlement bottle method for quantitative phytoplankton analysis, in Microscopic and Molecular Methods for Quantitative Phytoplankton Analysis, Karlson, B., Cusack, C., Bresnan, E. (Eds.), Intergovernmental Oceanographic Commission of UNESCO, Manuals and Guides No. 55, (IOC/2010/MG/55), pp.21-24.

McManus, M.A., Alldredge, A.L., Barnard, A.H., Boss, E., Case, J.F., Cowles, T.J., Donaghay, P.L., Eisner, L.B., Gifford, D.J., Greenlaw, C.F., Herren, C.M., Holliday, D.V., Johnson, D., MacIntyre, S., McGehee, D.M., Osborn, T.R., Perry, M.J., Pieper, R.E., Rines, J.E.B., Smith, D.C., Sullivan, J.M., Talbot, M.K., Twardowski, M.S., Weidemann, A. and Zaneveld, J.R., 2003. Characteristics, distribution and persistence of thin layers over a 48 hour period. Mar. Ecol. Prog. Ser. 261, 1-19.

McManus, M.A., Cheriton, O.M., Drake, P.J., Holliday, D.V., Storlazzi, C.D., Donaghay, P.L. and Greenlaw, C.F., 2005. Effects of physical processes on structure and transport of thin zooplankton layers in the coastal ocean. Mar. Ecol. Prog. Ser. 301, 199- 215.

McManus, M.A., Kudela, R.M., Silver, M.W., Steward, G.F., Donaghay, P.L. and Sullivan, J.M., 2008. Cryptic Blooms: Are Thin Layers the Missing Connection? Estuar. Coast. 31, 396-401.

Miles, J. W., 1963. On the stability of heterogeneous shear flows. Part 2. J. Fluid Mech. 16, 209-227. 
Ní Rathaille, A., 2007. Modelling Alexandrium bloom dynamics in Cork Harbour, Ireland. PhD Thesis, National University of Ireland, Galway. 277 pp.

Okubo, A 1971. Oceanic diffusion diagrams. Deep Sea Res., 18, 789-802

Osborn, T.R., 1998. Finestructure, microstructure and thin layers. Oceanography, 11(1), 36-43.

Rines, J.E.B., Donaghay, P.L., Dekshenieks, M.M., Sullivan, J.M., Twardowski, M.S., 2002. Thin layers and camouflage: hidden Pseudo-nitzschia spp. (Bacillariophyceae) populations in a fjord in the San Juan Islands, Washington, USA. Mar. Ecol. Prog. Ser. 225, 123-137.

Ryan, J.P., McManus, M.A., Paduan, J.D. and Chavez, F.P. 2008 Phytoplankton thin layers caused by shear in frontal zones of a coastal upwelling system. Mar. Ecol. Prog. Ser. 354, 21-34

Service Hydrographique et Océanographique de la Marine, France, 2005. Courants de Marée: Côte Sud de Bretagne. SHOM, 588.

Smayda, T.J., 2006. Harmful Algal Bloom Communities in Scottish Coastal Waters: Relationship to Fish Farming and Regional Comparisons-A Review. Scottish Executive Environment Group. 2006/3 ISBN0 7559131. Internet Publication: http:/ / www.scotland.gov.uk/Publications/2006/02/03095327/0.

Stacey, M.T., McManus, M.A. and Steinbuck, J.V. 2007 Convergences and divergences and thin layer formation and maintenance. Limnol. Oceanogr. 52(4), 1523-1532.

Steele, J.H., Yentsch, C.S., 1960. The vertical distribution of chlorophyll. J. Mar. Biol. Assoc UK 39(2), 217-226. 
Stock, C.A., McGillicuddy, D.J., Solow, A.R., D.M. Anderson. 2005. Evaluating hypotheses for the initiation and development of Alexandrium fundyense populations in the Gulf of Maine: . Deep Sea Res. II, 52, 27152744.

Sullivan, J.M., Donaghay, P.L., Rines, J.E.B., 2009. Coastal thin layer dynamics: Consequences to biology and optics. Cont. Shelf Res. 30(1) 50-65.

Tett, P., Edwards, A., Jones, K., 1986. A model for the growth of shelf-sea phytoplankton in summer. Estuar. Coast. Shelf Sci. 23, 641-672.

Thorpe, S.A., 2007. An Introduction to Ocean Turbulence. Cambridge University Press, 266 pp..

Tyler, M.,, Seliger, H.H., 1978. Annual subsurface transport of a red tide dinoflagellate to its bloom area: Water circulation patterns and organism distributions in the Chesapeake Bay. Limnol. Oceanogr. 23,227- 246.

Vanhoutte-Brunier, A., Fernand, L., Ménesguen, A., Lyons, S., Gohin, F., Cugier, P., 2008. Modelling the Karenia mikimotoi bloom that occurred in the western English Channel during summer 2003. Ecol. Model. 210(4) 351-376.

Velo-Suárez, L., González-Gil, S., Gentien, P., Lunven, M., Bechemin, C., Fernand, L., Raine, R., Reguera, B., 2008. Thin layers of Pseudo-nitzschia spp. and the fate of Dinophysis acuminata during an upwellingdownwelling cycle in a Galician Ría. Limnol. Oceanogr. 53(5), 1816-1834.

Xie, H., Lazure, P., Gentien, P., 2007. Small scale retentive structures and Dinophysis. J. Mar. Sys. 64, 173-188. 
Table 1. Satellite tracked drifter data based on three buoys drogued at $15 \mathrm{~m}$ in the Bay of Biscay during July 2006. The trajectories of each drifter are shown in Figure 1a.

\begin{tabular}{cccccc}
$\begin{array}{c}\text { Drifter } \\
\text { No. }\end{array}$ & $\begin{array}{c}\text { Deployment } \\
\text { Date }\end{array}$ & $\begin{array}{c}\text { Initial } \\
\text { Position }\end{array}$ & $\begin{array}{c}\text { Record } \\
\text { Length } \\
\text { (days) }\end{array}$ & $\begin{array}{c}\text { Mean } \\
\text { speed } \\
\left(\mathrm{m} \mathrm{s}^{-1}\right)\end{array}$ & $\begin{array}{c}\text { Direction } \\
{ }^{\circ} \text { from N) }\end{array}$ \\
\hline 1 & 09 July 2006 & $\begin{array}{c}46^{\circ} 24.0^{\prime} \mathrm{N} \\
02^{\circ} 14.4^{\prime} \mathrm{W}\end{array}$ & 9.5 & 0.052 & $160^{\circ}$ \\
2 & 10 July 2006 & $\begin{array}{l}47^{\circ} 05.4^{\prime} \mathrm{N} \\
02^{\circ} 46.2^{\prime} \mathrm{W} \\
47^{\circ} 24.6^{\prime} \mathrm{N} \\
02^{\circ} 29.4^{\prime} \mathrm{W}\end{array}$ & 5.6 & 0.055 & $145^{\circ}$ \\
3 & 11 July 2006 & 4.5 & 0.037 & $105^{\circ}$ \\
\hline
\end{tabular}


Table 2. Observations of cell densities of a haptophyte in the Bay of Biscay, 6-22 July, 2006. Stations were grouped into three divisions (see text). Station positions are shown in Figure 1a,b. Stations from Leg 2 (13-22 July) are in the corresponding geographic group to those of Leg 1 (6-12 July). Mean cell density ( $C$, cells $\left.\mathrm{m}^{-3}\right)$, the distance from the coast ( $\left.\mathrm{x}, \mathrm{km}\right)$ and the time between the survey legs were estimated for each group. Group I stations, closest to the coast, were assigned a distance value of $0 \mathrm{~km}$. From these the concentration gradient offshore $\left(\delta C / \delta x\left(\right.\right.$ cells $\left.\left.\mathrm{m}^{-3} \mathrm{~m}^{-1}\right)\right)$, the rate of change of the concentration offshore $\left(\delta^{2} \mathrm{C} / \delta x^{2}\left(\right.\right.$ cells $\left.\left.\mathrm{m}^{-3} \mathrm{~m}^{-1} \mathrm{~m}^{-1}\right)\right)$ and the change in concentration with time $(\delta \mathrm{C} / \delta t)$ were calculated.

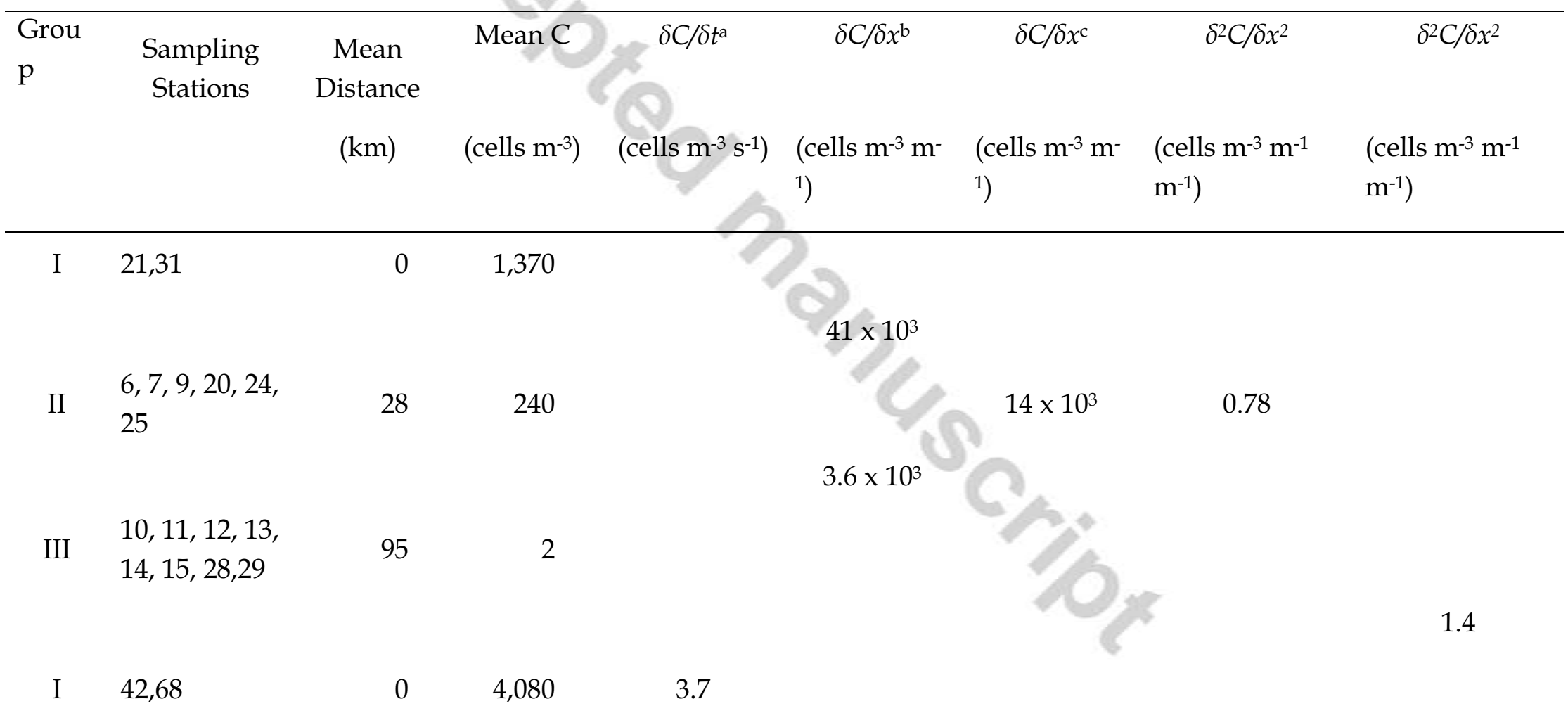


$93 \times 10^{3}$

II $\quad 59,60,62,67$

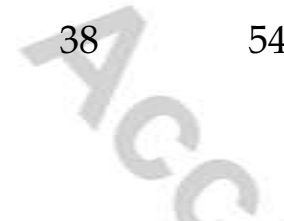

0.41

$53 \times 10^{3}$

2.1

$14 \times 10^{3}$

III $43,44,45,66$,

76

8.4

0.01

$71,75,76,77$

a Approximate time between legs $=8.5$ days $(734,000 \mathrm{~s})$

$\mathrm{b}$ between individual groups

$c$ across entire distance (Groups I-III) 
Table 3. Estimates of the vertical population gradient $\left(\delta^{2} \mathrm{C} / d z^{2}\right)$ above and below the vertical haptophyte maximum. Values are derived from observations of cell densities at station 62 (for location see Figure $1)$.

\begin{tabular}{rccc} 
Depth $(\mathrm{m})$ & Cells m-3 & $\begin{array}{c}\delta^{2} \mathrm{C} / d z^{2} \\
\left(\text { cells } \mathrm{m}^{-3} \mathrm{~m}^{-1} \mathrm{~m}^{-1}\right)\end{array}$ & $\begin{array}{c}\delta^{2} \mathrm{C} / d z^{2} \\
\left(\text { cells m} \mathrm{m}^{-3} \mathrm{~m}^{-1} \mathrm{~m}^{-1}\right) \\
(\text { down })\end{array}$ \\
\hline 8 & $11 \times 10^{6}$ & $51 \times 10^{6}$ & \\
17 & $470 \times 10^{6}$ & & \\
30 & $1.5 \times 10^{6}$ & & $22 \times 10^{6}$ \\
\hline
\end{tabular}


Table 4. Values calculated for determining the horizontal diffusive flux $\left(K_{x}\left(\delta^{2} C / d x^{2}\right)\right)$ of a haptophyte layer in the Bay of Biscay, France, July 2006. Derivation of values for the rate of change of cell density $(\delta C / d t)$, Horizontal advection $\left(U_{x}(\delta C / d x)\right)$, growth $(\mu C)$ and vertical diffusion $\left(K_{z}\left(\delta^{2} C / d z^{2}\right)\right)$ are described in the text.

\begin{tabular}{lcc} 
Term & Symbol & $\begin{array}{c}\text { Value } \\
\left(\text { cells m } \mathrm{m}^{-3} \mathrm{~s}^{-1}\right)\end{array}$ \\
\hline $\begin{array}{l}\text { Rate of change } \\
\text { of cell density }\end{array}$ & $\delta C / d t$ & $0.41 \times 10^{3}$ \\
$\begin{array}{l}\text { Horizontal } \\
\text { diffusive flux }\end{array}$ & $K_{x}\left(\delta^{2} \mathrm{C} / d x^{2}\right)$ & $K_{x} \times 1.4$ \\
$\begin{array}{l}\text { Horizontal } \\
\text { advection }\end{array}$ & $U_{x}(\delta \mathrm{C} / d x)$ & $-1.7 \times 10^{3}$ \\
$\begin{array}{l}\text { Growth } \\
\text { Vertical }\end{array}$ & $\mu \mathrm{C}$ & $+2.7 \times 10^{3}$ \\
diffusion & $K_{z}\left(\delta^{2} \mathrm{C} / d z^{2}\right)$ & $-0.87 \times 10^{3}$
\end{tabular}


Table 5. Derivation of parameters required for calculation of horizontal dispersal from the changes in the variance $\left(\sigma^{2}\right)$ of the mean density $\left(\mathrm{C}\right.$, cells $\left.\mathrm{m}^{-3}\right)$ of the population with time across the distance offshore $(x, m)$. Sampling locations were grouped into one of three divisions (see text).

\begin{tabular}{ccccc} 
Station Group & $\begin{array}{c}\text { Distance } \\
(x, \mathrm{~m})\end{array}$ & $\begin{array}{c}\text { Mean C } \\
\left(\text { cells m }{ }^{-3}\right)\end{array}$ & $x . \mathrm{C}$ & Result \\
\hline Group I & 0 & 4100 & 0 & \\
Group II & 38000 & 540 & 20520 & \\
Group III & 76000 & 8.4 & 630 & 4480 \\
$\begin{array}{l}\text { Mean distance }(\mathrm{m}) \\
=\sum(\mathrm{x} . \mathrm{C}) / \sum(\mathrm{C})\end{array}$ & & & & \\
$\begin{array}{l}\text { Variance } \sigma^{2}\left(\text { cells } \mathrm{m}^{2}\right) \\
=\sum\left(\mathrm{C} .\left(\mathrm{x}-\mathrm{x}^{-}\right)^{2}\right) / \sum(\mathrm{C})\end{array}$ & & & & $1.55 \times 10^{8}$ \\
\hline
\end{tabular}




\section{List of Figures}

Figure 1 Map of the study area in the northeastern Bay of Biscay, France. The location of sampling stations occupied between 6-12 July, 2006 are shown as small filled circles. The location of selected stations sampled between 18-20 July are shown (stations 60, 62, 68 and 71) and the track of Scanfish tows 56 (17 July, 2006) and 72 (20 July 2006).

A map of the study area in the northeast Bay of Biscay, France. The location of sampling stations for (a) leg 1 (6-12 July, 2006) and (b) leg 2 (13-22 July, 2006) are shown. The track of Scanfish tows during leg 2 are shown in (c). Drifter deployment positions and their tracks are shown in Figure 1a.

Figure 2. The distribution of near surface $(5 \mathrm{~m})$ a) temperature $\left({ }^{\circ} \mathrm{C}\right)$ and $\mathrm{b}$ ) surface salinity respectively collected between 6-12 July, 2006; c) continuous surface underway salinity and chlorophyll fluorescence record between stations 9 and 13 (Figure 1a) 7-8 July 2006 in the northeastern Bay of Biscay.

Figure 3. Distribution of density (sigma-t, $\mathrm{kg} \mathrm{m}^{-3}$ ) and chlorophyll fluorescence (chlorophyll a equivalents, $\mu \mathrm{g} \mathrm{l}^{-1}$ ) along Scanfish sections (a) 72 (20 July, 2006, see Figure 1) and (b) 56 (17 July, 2006, see Figure 1). For each transect, the horizontal scales are shown as longitude and as distance in kilometres relative to the start of the transect.

Figure 4. Plot of nutrients (Nitrate) against salinity for stations 1-37, northeastern Bay of Biscay, 6-12 July 2005.

Figure 5: (a) Map showing the distribution of phytoplankton community groups as delineated by multivariate analysis of phytoplankton species observed at the depth of the fluorescence maximum at sampling stations during the first leg of the survey (6-12 July, 2006). Station groups were based on the presence/absence of certain type species indicated in the dendrogram 
in panel (b). (c) and (d) Distribution of the dominant haptophyte population during the first (c) and second (d) parts of the survey.

Figure 6: Microphotographs of the dominant haptophyte observed during the survey. (a) Lugol's iodine preserved cell (scale bar $=20 \mathrm{um}$ ); (b) TEM of whole cell, flagellae and haptonema (scale bar $=2 \mu \mathrm{m}$ ); (c - e) TEM images of dominant scale types; (f-g) TEM images of both sides of a third, less frequently occurring scale type with spine.

Figure 7: Vertical distributions of chlorophyll $a$ fluorescence and the cell density of the unidentified haptophyte species shown in Figure 4 at locations close to the mouth of the River Loire. This location was repeatedly sampled throughout the survey; (a) Station 21, 9 July; (b) Station 31, 11 July; (c) Station 42, 15 July; (d) Station 68, 19 July 2006. Note the varying scales of chlorophyll $a$ fluorescence and cell concentrations of the haptophyte between profiles.

Figure 8. Vertical distribution of water density, chlorophyll fluorescence and cell concentrations of the haptophyte shown in Figure 4 in relation to the physical parameters at stations $60(\mathrm{a}-\mathrm{d})$ and $71(\mathrm{e}-\mathrm{h})$. The distributions can be compared with $(b, f)$ the Brunt Väisälä frequency N2; shear $(c, g)$ horizontal shear and $(\mathrm{d}, \mathrm{h})$ the Richardson number Ri. 

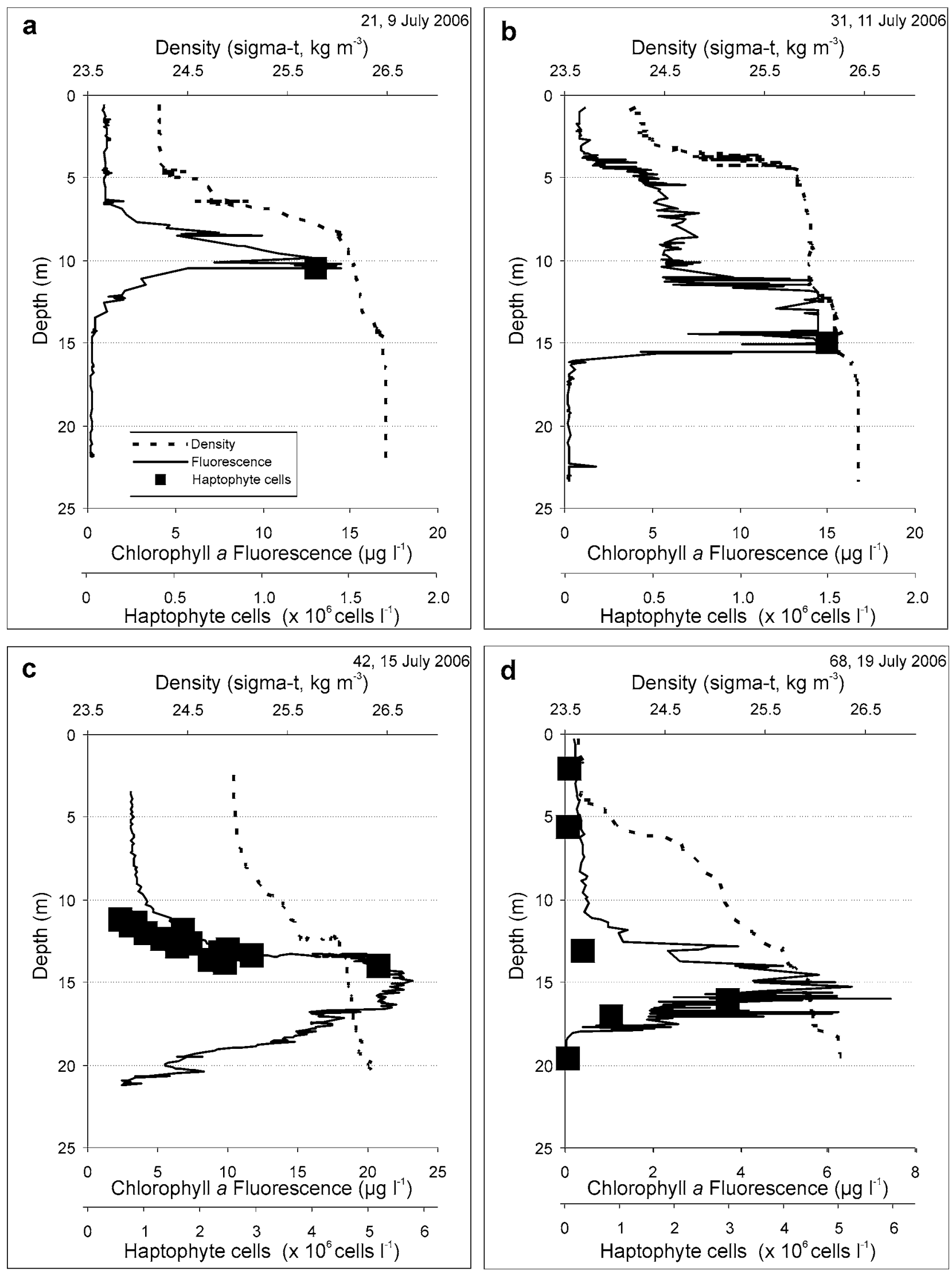

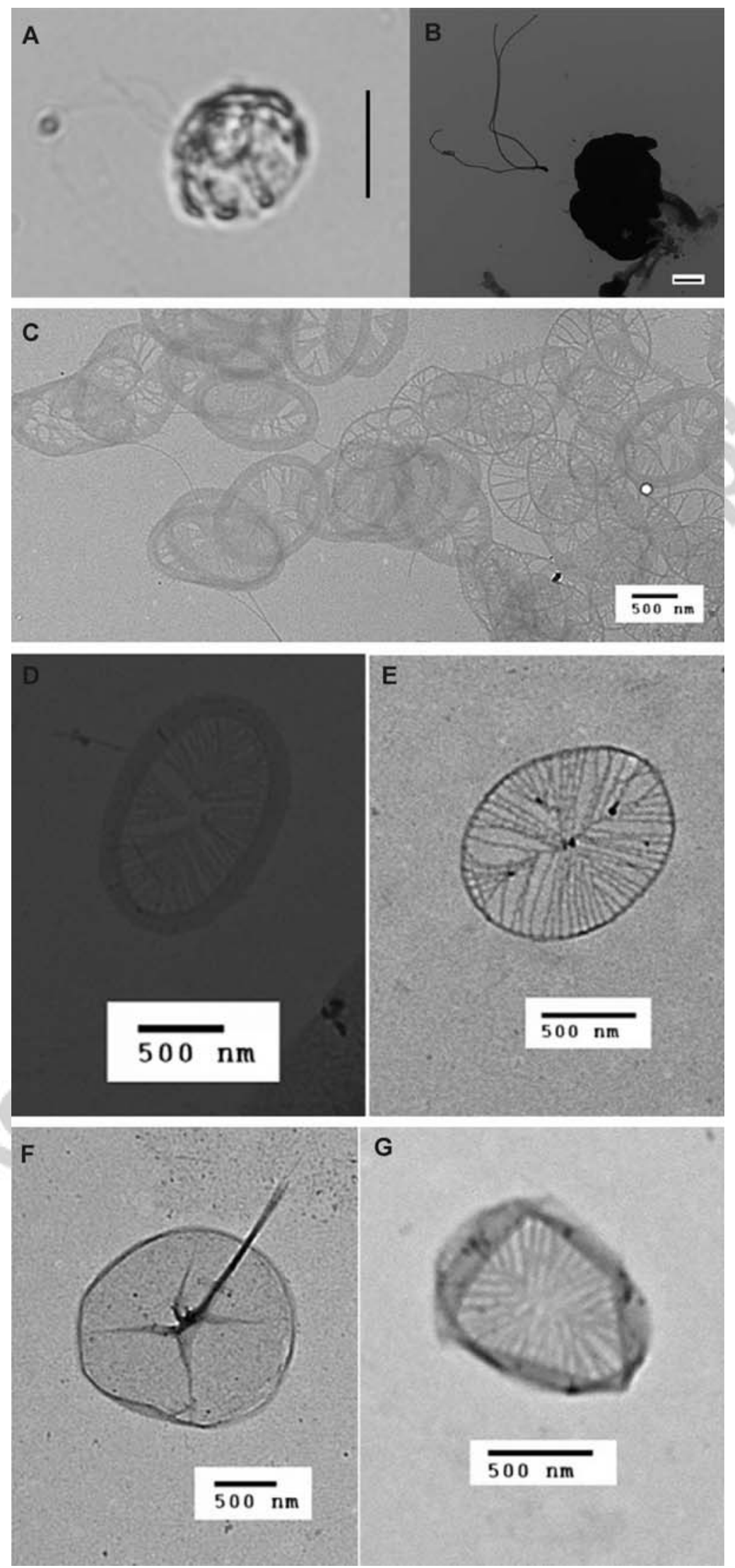


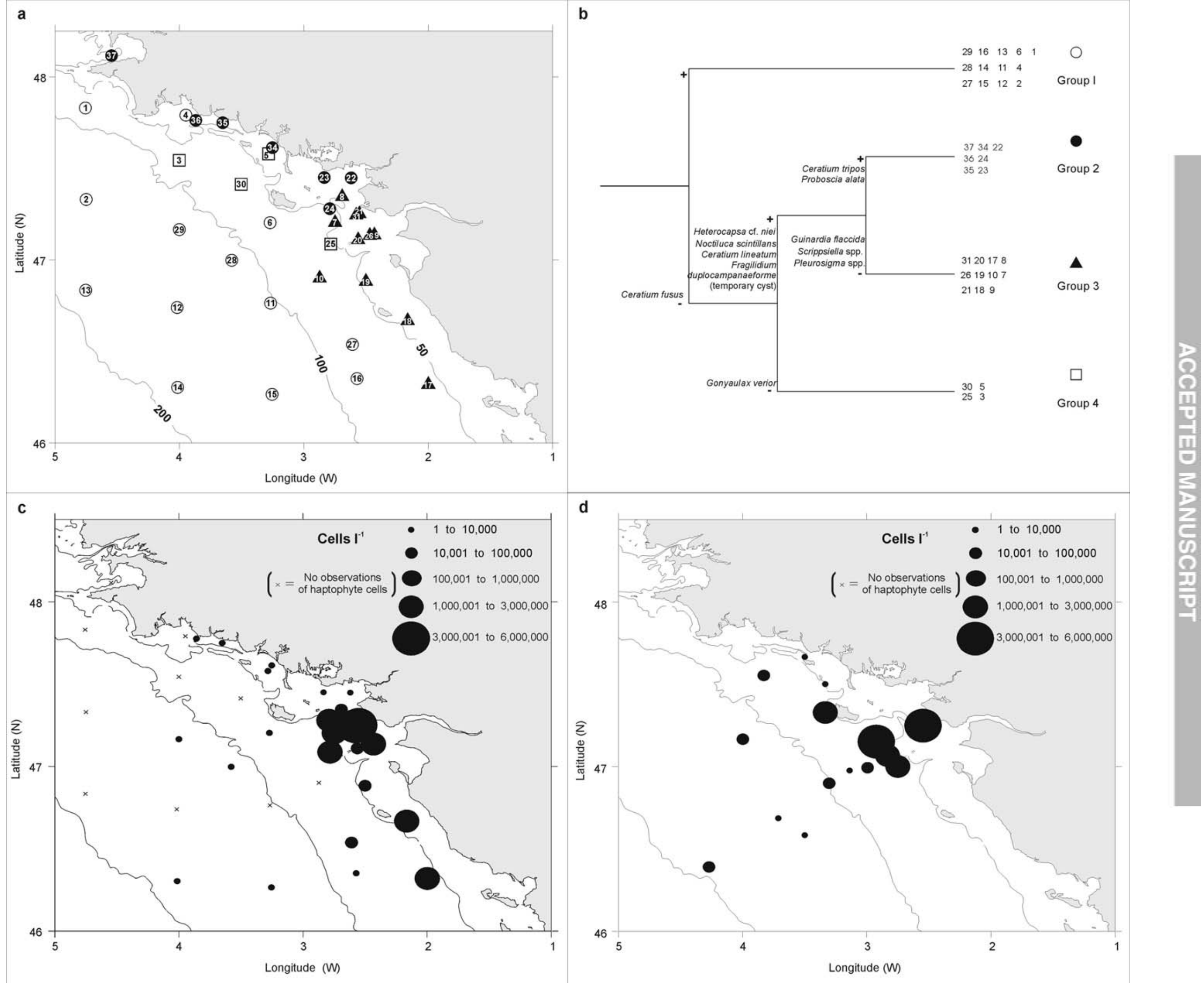




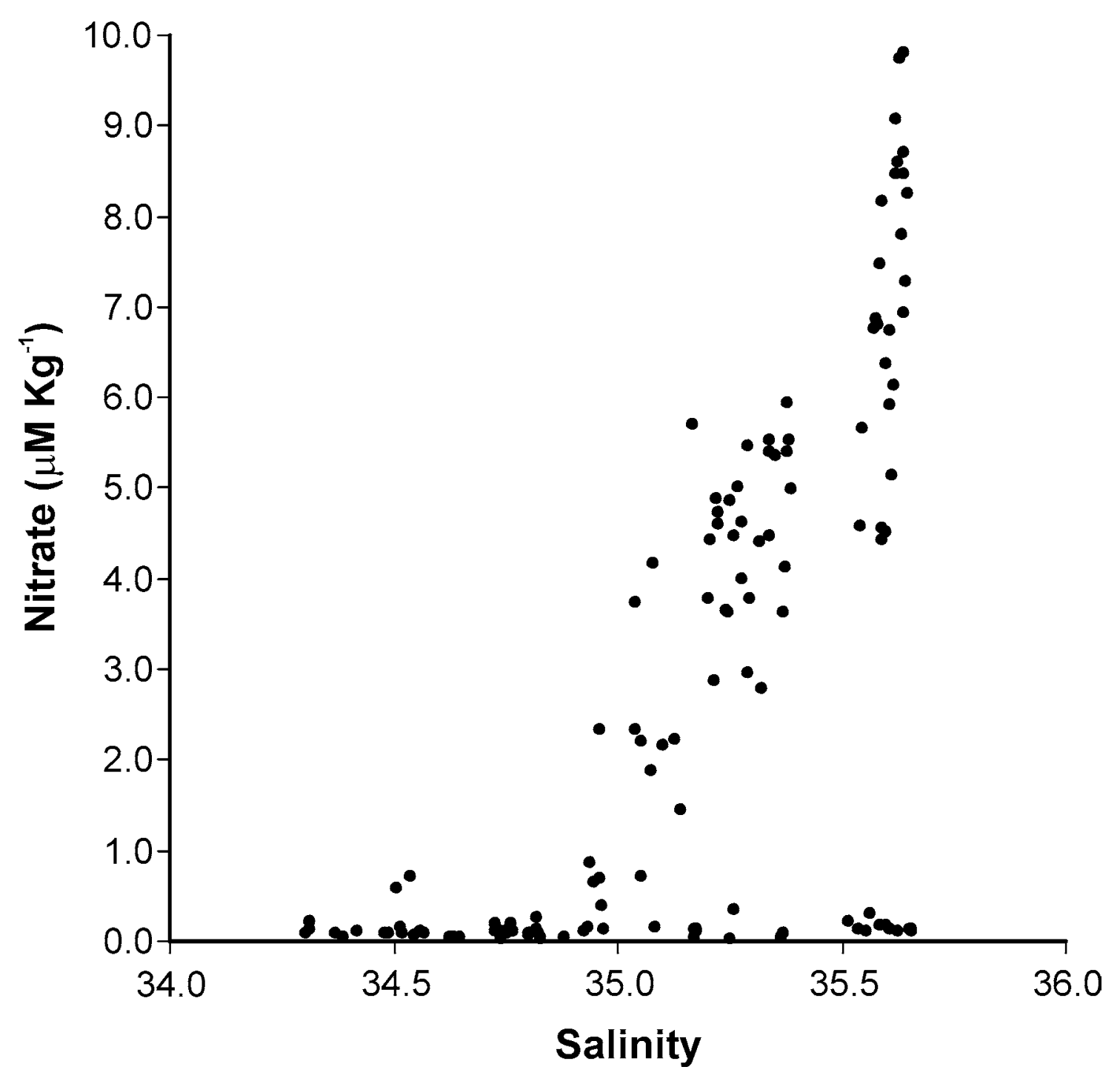




\section{Longitude (W)}

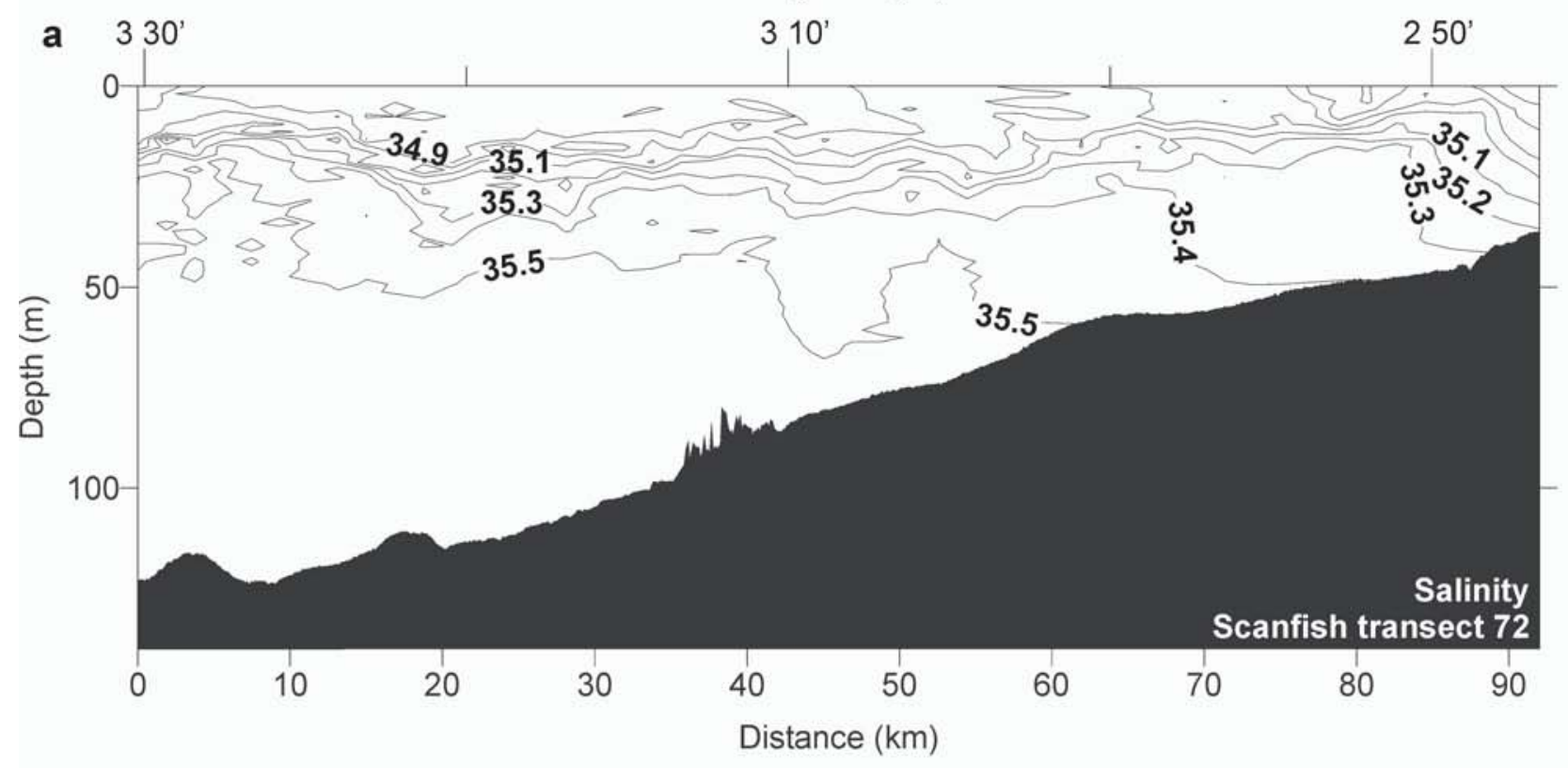

Longitude (W)
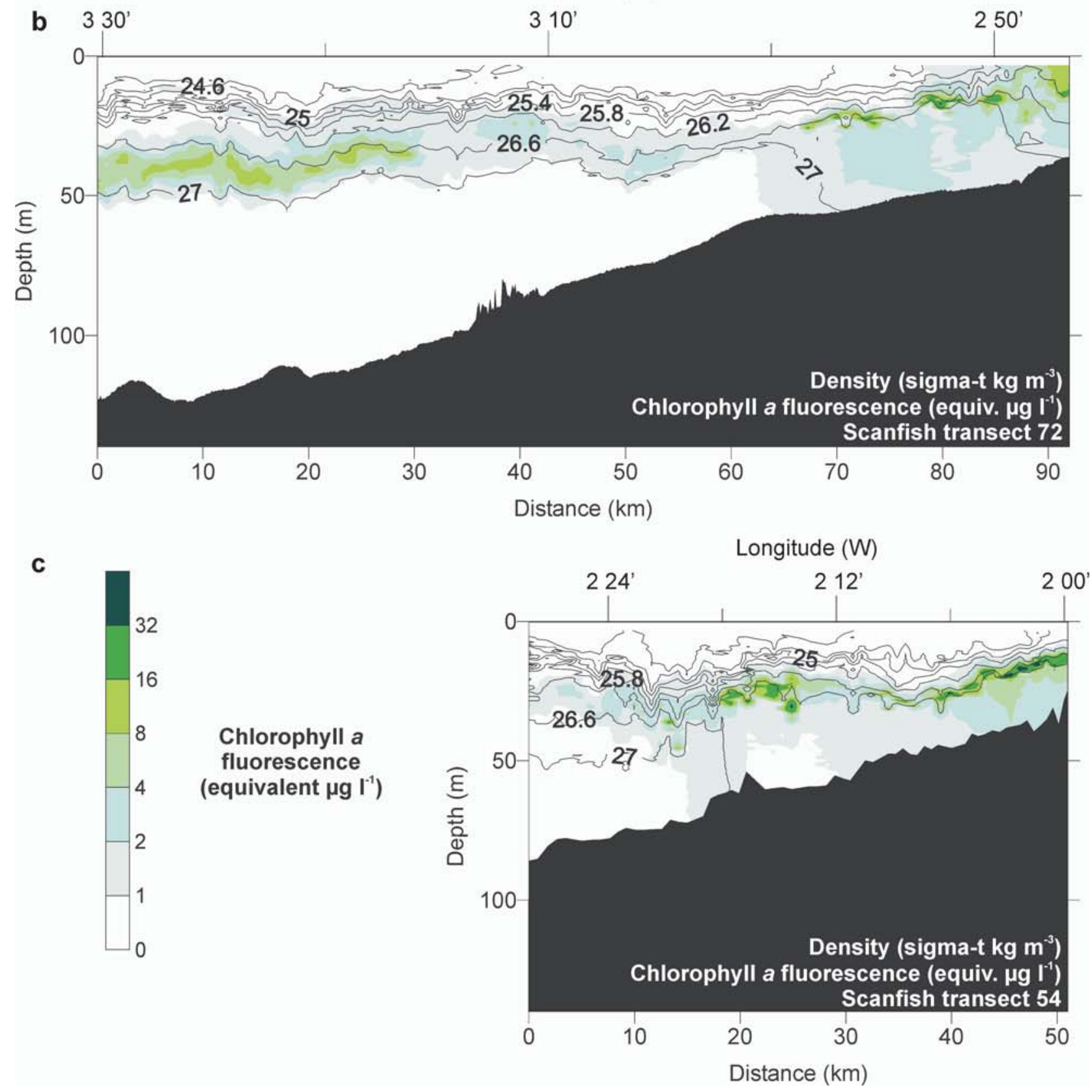

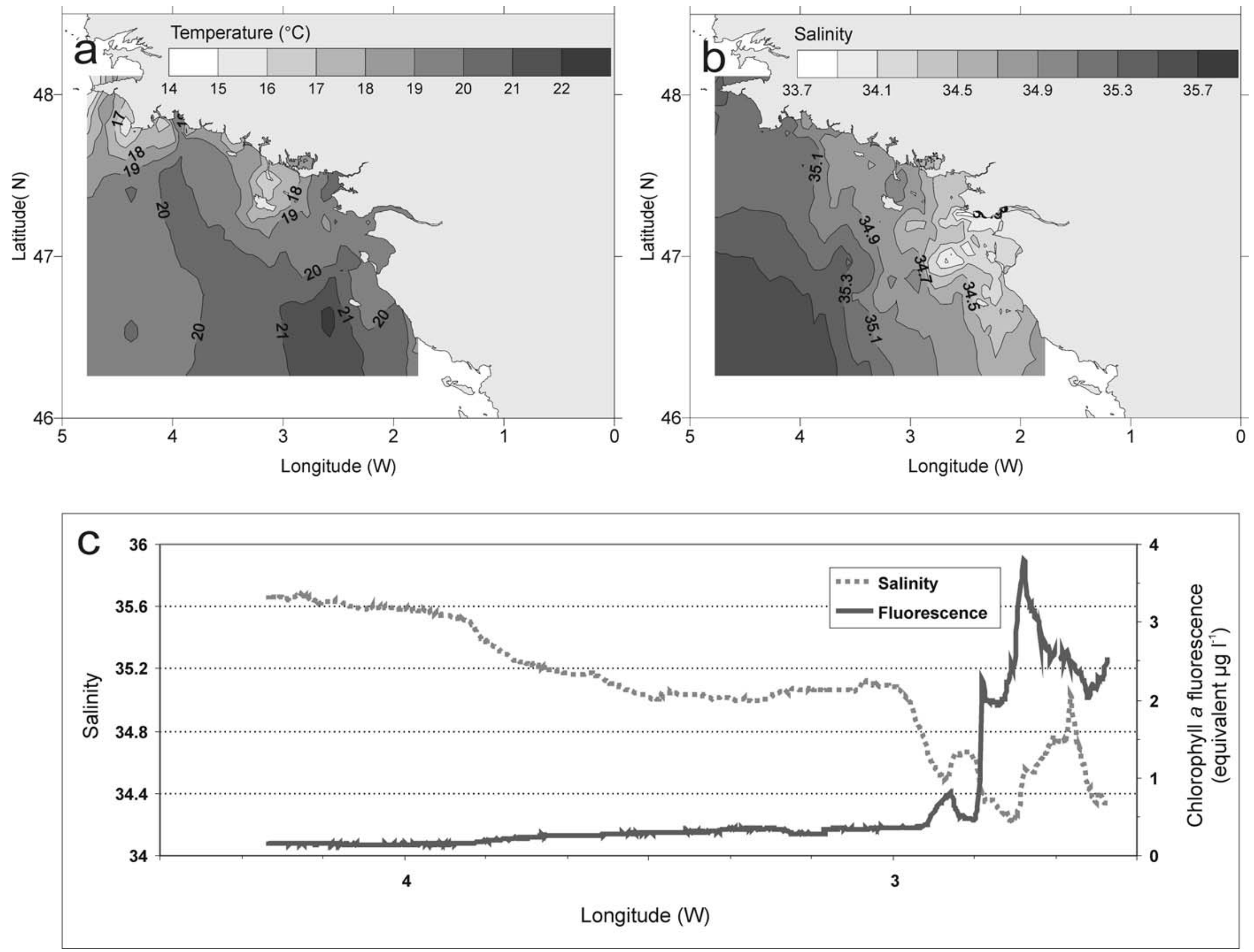

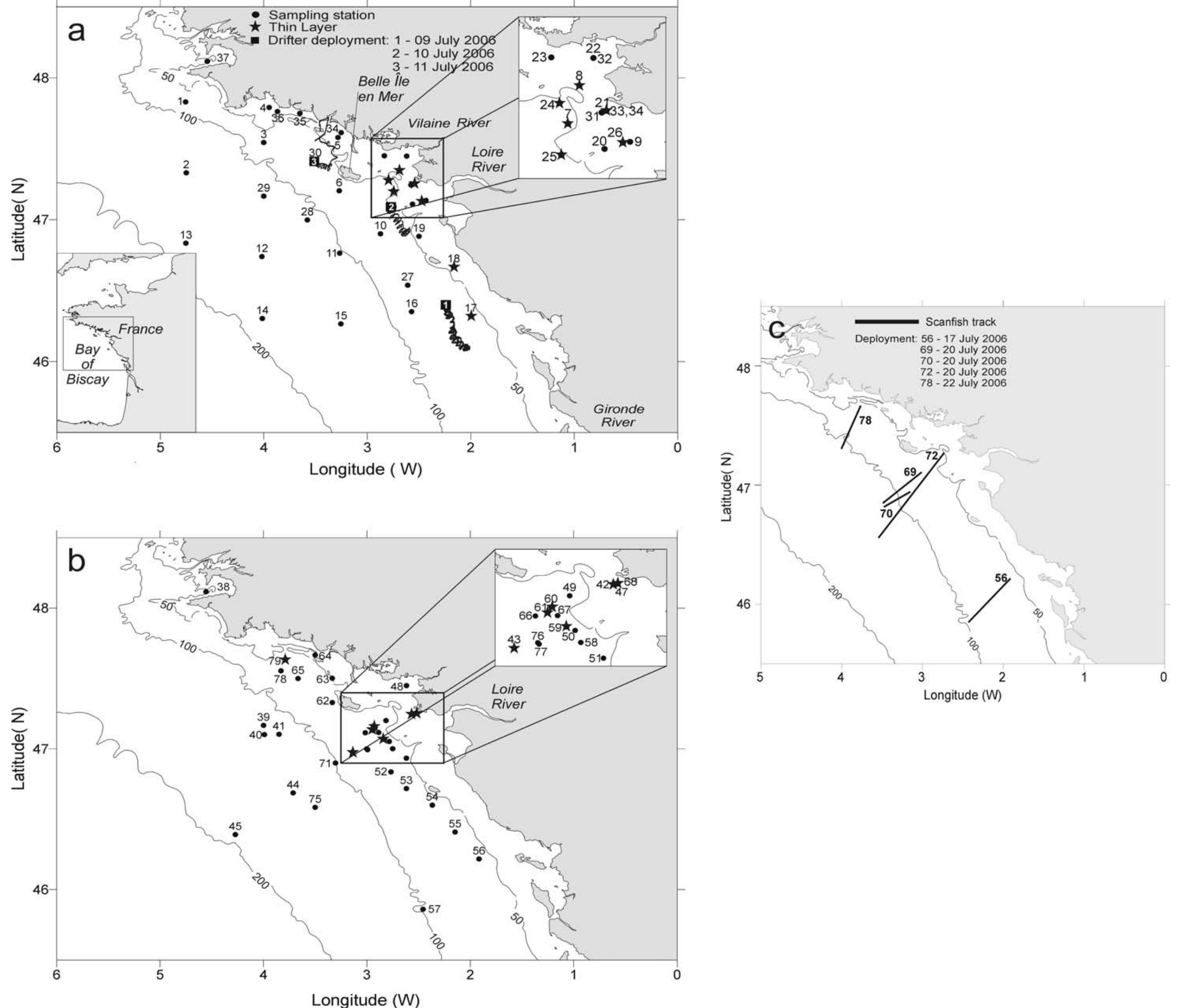


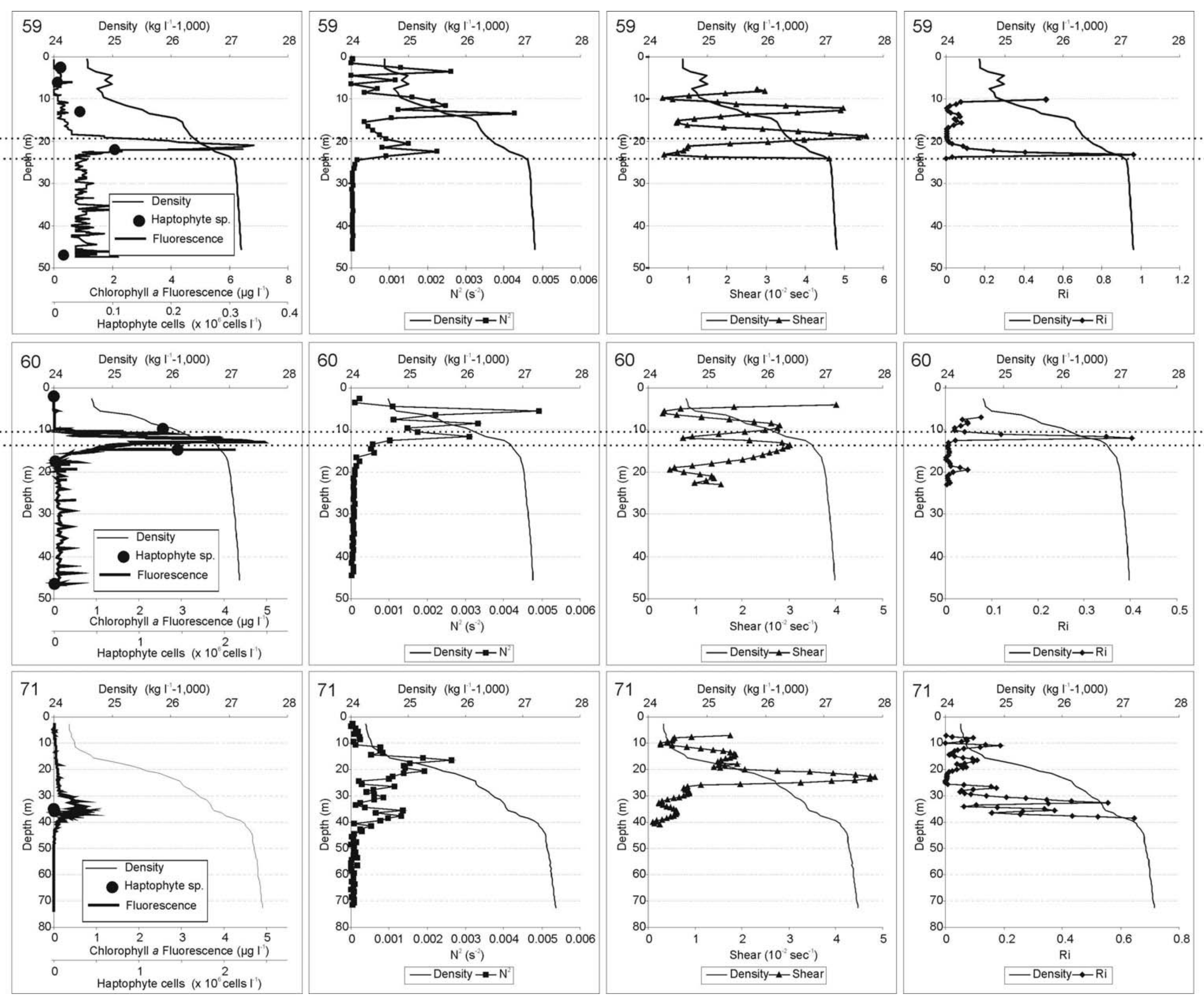

